\title{
Impact of Antioxidant Natural Compounds on the Thyroid Gland and Implication of the Keap1/Nrf2 Signaling Pathway
}

\author{
Ana Paunkov ${ }^{\mathrm{a}}$, Dionysios V. Chartoumpekis ${ }^{\mathrm{b}}$, Panos G. Ziros ${ }^{\mathrm{a}}$ Niki Chondrogianni ${ }^{\mathrm{c}}$, Thomas W. Kensler ${ }^{\mathrm{d}}$ and \\ Gerasimos P. Sykiotis ${ }^{\mathrm{a}^{*}}$
}

\begin{abstract}
${ }^{a}$ Service of Endocrinology, Diabetology and Metabolism, University of Lausanne, Lausanne, Switzerland; ${ }^{b}$ Department of Internal Medicine, Endocrinology Unit, Patras University Medical School, Patras, Greece; ${ }^{c}$ Institute of Biology, Medicinal Chemistry and Biotechnology, National Hellenic Research Foundation, Athens, Greece; ${ }^{d}$ Public Health Sciences Division, Fred Hutchinson Cancer Research Center, Seattle, WA, USA
\end{abstract}

\begin{abstract}
Background: Natural compounds with potential antioxidant properties have been used in the form of food supplements or extracts with the intent to prevent or treat various diseases. Many of these compounds can activate the cytoprotective Nrf2 pathway. Besides, some of them are known to impact the thyroid gland, often with potential side-effects, but in other instances, with potential utility in the treatment of thyroid disorders.

Objective: In view of recent data regarding the multiple roles of Nrf2 in the thyroid, this review summarizes the current bibliography on natural compounds that can have an effect on thyroid gland physiology and pathophysiology, and it discusses the potential implication of the Nrf2 system in the respective mechanisms.

Method \& Results: Literature searches for articles from 1950 to 2018 were performed in PubMed and Google Scholar using relevant keywords about phytochemicals, Nrf2 and thyroid. Natural substances were categorized into phenolic compounds, sulfur-containing compounds, quinones, terpenoids, or under the general category of plant extracts. For individual compounds in each category, respective data were summarized, as derived from in vitro (cell lines), preclinical (animal models) and clinical studies. The main emerging themes were as follows: phenolic compounds often showed potential to affect the production of thyroid hormones; sulfur-containing compounds impacted the pathogenesis of goiter and the proliferation of thyroid cancer cells; while quinones and terpenoids modified Nrf2 signaling in thyroid cell lines.

Conclusion: Natural compounds that modify the activity of the Nrf2 pathway should be evaluated carefully, not only for their potential to be used as therapeutic agents for thyroid disorders, but also for their thyroidal safety when used for the prevention and treatment of non-thyroidal diseases.
\end{abstract}

A R T I C L E H I S T O R Y

Received: April 1, 2019

Accepted: June 20, 2019

DOI:

$10.2174 / 1381612825666190701165821$

Keywords: Personalized nutrition, phytochemical, flavonoid, Nrf2, thyroid, goiter, hyperthyroidism, hypothyroidism.

\section{INTRODUCTION}

Food contains chemical compounds with potential ability to impact human health, either positively or negatively, by altering enzymatic reactions, cell signaling, and other biological processes [1]. Consumption of vegetables, fruits and whole grains can provide non-nutrient bioactive compounds, also known as phytochemicals, which can be involved in stimulation of the immune system, hormone metabolism, scavenging of oxidants, regulation of genes implicated in cell proliferation or apoptosis, antiviral and antibacterial processes, etc. Such compounds can potentially reduce the risk of diabetes, cardiovascular diseases, Alzheimer's disease and other aging-related disorders [2-4]. Changing dietary habits in favor of plant-based foods may thus provide health benefits beyond the provision of basic nutrients. Adding fruits and vegetables rich in phytochemicals into a diet is therefore promoted as a strategy for the prevention of chronic diseases. One plausible contributing mechanism is that phytochemicals can provide protection against reactive oxygen species (ROS), thereby reducing the risk of various pathological processes and diseases related to oxidative stress [5]. According to their mechanisms of action that confer protection against ROS, phytochemicals with antioxidant activity can be classified into (i) direct antioxidants, which are redox-active and have short half-lives; (ii) indirect antioxidants, which induce intracellular

*Address correspondence to this author at the Service of Endocrinology, Lausanne University Hospital, Lausanne, Switzerland; Tel/Fax: ++41-079556-1494; E-mail: gerasimos.sykiotis@chuv.ch pathways that can ultimately protect against oxidative stress; and (iii) bifunctional antioxidants, which have both properties [6]. However, the beneficial effect of natural compounds is often overemphasized, whereas data about potential toxicities associated with excess intake are in general scarce. Taking into account the classic principle of toxicology that "the dose makes the poison", careful consideration should be given to the effects of the various phytochemicals that are mainly consumed in the form of food supplements, often without having undergone rigorous toxicological or clinical safety testing. Consequently, low levels of phytochemicals present in fruits and vegetables may offer health benefits, but these same compounds may be ineffective or even unsafe when consumed at higher doses [7].

The transcription factor Nrf2 (nuclear factor erythroid 2-related factor 2) is a major effector of antioxidant cellular responses and a target of phytochemicals, with protective effects against oxidative stress-related diseases $[8,9]$. These phytochemicals are thus considered indirect antioxidants. Under basal conditions, $\mathrm{Nrf} 2$ is sequestered in the cytoplasm by the cysteine-rich protein Keap 1 (Kelch-like ECH-associated protein 1) that facilitates its ubiquitination and its subsequent degradation by the proteasome [10]. The sulfhydryl (-SH) groups of Keap1 cysteines act as "sensors" [11] that react with oxidative or electrophilic stressors or pharmacological inducers of the Keap1/Nrf2 pathway to provoke conformational changes in Keap1 that render it incapable of facilitating the degradation of Nrf2 molecules. Thus, de novo transcribed and translated Nrf2 can accumulate and, after various post-translational modifications, can enter the nucleus and induce the expression of its target 
genes by binding to conserved ARE (Antioxidant Response Element) sequences in their regulatory regions. Classic target genes of Nrf2 comprise cytoprotective and antioxidant enzymes such as heme oxygenase-1, NAD(P)H-quinone oxidoreductase-1, glutamate cysteine ligase, glutathione peroxidase, glutathione S-transferases, thioredoxin, thioredoxin reductase, and many others, including mediators of secondary antioxidant mechanisms, such as several proteasome subunits [12]. Pharmacological inducers of Nrf2 interact with specific Keap1 cysteines and activate the Nrf2 pathway [13]. A very well characterized Nrf2 activator that can be found in its precursor form in natural products (cruciferous vegetables and especially broccoli) is the isothiocyanate sulforaphane [14-16]. Sulforaphane-rich broccoli sprouts extracts have been extensively used in series of preclinical and clinical studies, with the majority of them addressing the field of cancer chemoprevention, where sulforaphane has been proven effective against both genetic and chemical models of carcinogenesis in rodents [17]. As the use of sulforaphane in clinical trials has been expanding, it has been shown to enhance the detoxification of air pollutants [18], repress hepatic glucose production [19], and even ameliorate symptoms of autism spectrum disorder [20].

Nrf2 is activated not only by sulforaphane but by many other phytochemicals. Broadly, natural compounds that can directly react with Keap 1 cysteines or can induce low-level oxidative stress, may have the potential to induce the Nrf2 pathway, possibly along with other pathways [21]. Because very few studies have specifically focused on the potential impact of phytochemical-mediated Nrf2 modulation on the thyroid gland and its pathologies, this minireview focuses on redox-active natural compounds that may affect the thyroid gland and may implicate the Nrf2 pathway as a mechanism of action.

\subsection{Thyroid Gland Physiology and Hormone Synthesis}

Normal anatomy and function of the thyroid gland, and normal concentration of thyroid hormones, are crucial prerequisites for optimal growth and development. Disorders of thyroid gland function, namely hyperthyroidism (hyperfunction) and hypothyroidism (hypofunction), as well as of thyroid anatomy, namely goiter (thyroid enlargement), are among the most common endocrine diseases. Though they can affect subjects of all ages, it is well documented that their prevalence increases with age [22-27]. Many substances and conditions are able to affect thyroid hormone biosynthesis and metabolism, including environmental and dietary factors, particularly in areas characterized by nutritional iodine deficiency [28, 29].

The thyroid gland synthesizes and secretes two main thyroid hormones, the highly active triiodothyronine (T3) and its much less active precursor, thyroxine (T4). For thyroid hormone synthesis to take place, it is necessary that the pituitary hormone thyrotropin (thyroid-stimulating hormone, TSH) binds to its receptor on the basolateral membrane of thyrocytes. The synthesis and secretion of TSH by the pituitary are stimulated by thyrotropin-releasing hormone (TRH), which is secreted by the hypothalamus into the hypothalamic-pituitary portal vein system. In turn, optimal serum levels of thyroid hormone are ensured principally due to the inhibitory effects of circulating T4 and of T3 on the secretion of TSH and TRH (the so-called negative feedback loop) [30].

Another essential aspect for thyroid hormone synthesis is the particular organization of thyroid tissue and especially the polarity of thyroid follicular cells. The thyroid is comprised of follicles, spherical structures that represent the gland's secretory and functional units. Every thyroid follicle consists of grouped thyroid epithelial cells forming a spherical monolayer around a lumen filled with a viscous substance called colloid. Thyroid hormone synthesis takes place in the colloid, facing the apical plasma of thyrocytes. The opposite, basolateral side, is in contact with a network of blood capillaries, into which, the final synthesized thyroid hormones are secreted.
From the same capillaries, iodide $\left(\mathrm{I}^{-}\right.$, the negatively charged anionic form of iodine) is taken up into the cells through the sodium $\left(\mathrm{Na}^{+}\right) /$iodide $\left(\mathrm{I}^{-}\right)$symporter (NIS), in order to be used for thyroid hormone synthesis [31]. Iodide is then transported towards the follicular lumen ("iodine efflux"), in a process involving apical plasma membrane channels such as pendrin and anoctamin [32-34].

In addition to iodide, the other main structural component required for thyroid hormone synthesis is thyroglobulin (Tg), a high molecular weight protein synthesized by the endoplasmic reticulum of thyrocytes. Iodide and Tg are brought together via the actions of thyroid peroxidase (TPO), an oxidoreductase enzyme localized at the apical plasma membrane that catalyzes a number of consecutive reactions. In the first step, iodide is oxidized by TPO in a reaction that requires hydrogen peroxide $\left(\mathrm{H}_{2} \mathrm{O}_{2}\right)$, actively generated in thyrocytes by the enzyme, dual oxidase (DUOX, a NADPH oxidase) [35]. Oxidized iodide then binds to tyrosyl residues of Tg in a process called Tg iodination or iodine organification; this process results in the formation of monoiodotyrosines (MIT) and diiodotyrosines (DIT) on the Tg molecule. In the next step, T3 and T4 are formed by the coupling of two iodotyrosines, one MIT and one DIT for T3, or two DIT for T4 [36]. When demand for thyroid hormone secretion is low or absent, $\mathrm{Tg}$ is stored in the follicular lumen. Once needed, Tg enters the thyrocytes by micropinocytosis, whereby it is packed in vesicles. Inside the thyrocytes, these vesicles fuse with lysosomes, facilitating a proteolytic breakdown of $\mathrm{Tg}$ mediated by enzymes like cathepsin B, D and L. This is followed by degradation reactions catalyzed by lysosomal dipeptidase I, dipeptidylpeptidases I and II and N-acetyl-1-phenylalanyl-L-tyrosine hydrolase $[37,38]$. Together, these reactions lead to the release of T3 and T4 from Tg. MIT and DIT undergo deiodination by the enzyme dehalogenase 1 (DEHAL1) that recycles iodide to be reused by thyrocytes, thus economizing on this trace element [39].

\subsection{Role of Nrf2 in the Thyroidal Antioxidant Response}

In general, tissues that generate high amounts of free radicals (e.g., muscle) or have functions in detoxification (e.g., liver) are more susceptible to disorders caused by oxidative stress. As mentioned, in order to synthesize thyroid hormones, follicular cells require a constant physiological generation of $\mathrm{H}_{2} \mathrm{O}_{2}$ as the initiator of a series of oxidation reactions that result in the organification of iodide by the iodination of Tg. It is therefore not surprising that defense against oxidative stress is particularly vital for thyrocytes. Yet, in comparison to other tissues, relatively little is known about the role of proteostatic and antioxidant systems in the thyroid [24]. While a minimal amount of oxidative load is necessary in order for thyrocytes to proliferate and function normally [40, 41], intrathyroidal oxidative stress occurs during pathological conditions like goitrogenesis or iodine deficiency, and this in turn activates the thyroid's antioxidant defenses [42-45].

Recent work has shown that Nrf2 signaling has a central role in the antioxidant response of the thyroid gland [43]. Nrf2 regulates the expression levels of genes like thioredoxin reductase 1 and glutathione peroxidase 2 [43], which are known to maintain homeostasis in thyroid cells by ameliorating oxidative insults [46, 47]. In addition, Nrf2 protects the thyroid from oxidative damage induced by iodide overload [43]. Importantly, Nrf2 coordinates antioxidant defense in the thyroid gland with Tg production and iodination, and it can actually regulate the transcription of the gene encoding Tg by binding to two ARE sequences in a conserved enhancer [43].

Regulation of $\mathrm{Tg}$ expression by $\mathrm{Nrf} 2$ makes biological and physiological sense, because both the Tg folding process and the iodination of $\mathrm{Tg}$ are mediated by oxidation reactions, as discussed above. For normal follicular function with optimal Tg economy, it is necessary to coordinate the regulation of antioxidant defense by Nrf2 with Tg production and iodination. Under normal conditions, Nrf2 prevents excessive Tg iodination by reducing ROS levels via a positive control of the expression of antioxidant genes. The role of 
$\mathrm{Nrf} 2$ in protection from oxidative stress is even more important during iodide overload: as a response to high iodide intake, Nrf2 activates a transcriptional program that limits ROS levels, preventing oxidative damage to biomolecules in follicular cells [43, 48, 49]. Other genes involved in the specification, differentiation or function of thyroid follicular cells may also be impacted by Nrf2. Yet, in contrast to $\mathrm{Tg}$, such regulation is apparently indirect and could result from the general redox status of the cell and/or from the crosstalk of Nrf2 with other pathways, as has been described also in other tissues [50-52]. Interestingly, when high doses of iodide were provided to mice lacking NIS, Tg iodination and thyroid hormone synthesis proceeded successfully to a certain degree [53]. In these conditions, a decrease in the mRNA levels of Nrf2 and of various antioxidant genes was also observed. Together, these data suggest that elevated TSH levels lead to a repression of Nrf2 signaling in order to increase ROS levels, which in turn favors the oxidative reactions necessary for $\mathrm{Tg}$ iodination and thyroid hormone synthesis $[43,54]$.

Beyond its protective and physiological roles in normal thyroid, Nrf2 signaling has also been found to be activated in thyroid carcinomas, where it confers protection against oxidative stress and resistance to antineoplastic agents $[55,56]$.

\subsection{Research aims and Strategy}

The aim of this paper was to review the literature regarding natural substances with the potential to affect the physiology or pathophysiology of the thyroid gland, with a focus on those that are known to modulate the activity of $\mathrm{Nrf} 2$ as a mechanism of antioxidant response. The ultimate goal was to assess the need for future studies on such compounds regarding their thyroidal effects and the estimation of doses that can be beneficial or at least safe for the thyroid gland.

The literature search and selection of articles for this minireview was conducted using Pubmed and Google Scholar for articles published in English from January 1950, through July, 2018. The following search terms were used: "natural compounds" or "natural substances" or "dietary flavonoids" or "phytochemicals" or "extracts" or "nutraceuticals" or "natural products", in combination with "Nrf2" or "Nrf2 activation" or "Nrf2 inhibition" or "Nrf2 modulation" or "Nrf2 pathway", and "thyroid" or "antithyroid" or "goiter" or "goitre" or "goitrogenic". To determine the relevance of publications, abstracts and/or titles were screened. Next, the full texts of selected studies were reviewed and all relevant references cited in these studies were also screened and included when pertinent. For compounds shown to have an effect on Nrf2, the literature was checked for any known activities in the thyroid, and vice versa.

In this manner, we identified, in particular, studies providing evidence regarding different effects of natural compounds on thyroid gland morphology and/or function. Regarding the involvement of Nrf2 as a mechanism of action of these compounds, we included only studies providing experimental evidence; papers with speculative but experimentally unsupported mechanisms were excluded.

\section{PHENOLIC COMPOUNDS}

Plants have the ability to synthesize secondary metabolites, including phenolic compounds [57]. In plants, these compounds play various roles during interactions with the environment, such as in the protection against ultraviolet radiation, in the attraction of seed-dispersing animals or pollinators, as well as in the defense against predators, parasites and pathogens [58]. Aside from providing plants with adaptive or survival strategies, phenolic compounds have commercial significance, because they are being used in the production of fibers, dyes, oils, flavoring agents and perfumes, and also as a source of new antibiotics, natural drugs, herbicides and insecticides $[59,60]$. This makes phenolic compounds a main research focus for many scientists globally. Currently, around 8000 phenolic compounds are known; they demonstrate wide structural diversity, ranging from simple phenolic acids to polyphenols (like flavonoids) to polymeric compounds. Flavonoids comprise the largest and most studied group among phenolic compounds; they are present in vegetables, fruits, spices, seeds, nuts, red wine and tea, and they are usually classified into isoflavonoids, flavanones, flavonols, flavanols (catechins), flavones, anthocyanidins and chalcones [61].

Phenolic compounds originating from medicinal herbs and dietary plants have various biological activities, including modulation of enzyme activities involved in oxidation and detoxification, as well as antiviral, antibacterial, anticancer, and anti-inflammatory effects[62].

\subsection{Effects of Phenolic Compounds on Thyroid}

Numerous conditions and chemical substances can alter thyroid function and affect the secretion of thyroid hormones and/or their availability to target tissues. Flavonoids, the largest class of phenolic compounds, present in dietary plants and medical herbs, can interfere with thyroid hormone economy [29]. For example, in one of their first reported antithyroid effects, rats fed arachidoside and anacardioside pigments isolated from nuts developed goiter [63].

Exposure to flavones apigenin, chrysin, vitexin and baicalein, present in parsley, cherries, thyme, olives, tea and broccoli, can inhibit TPO, the essential enzyme for thyroid hormone synthesis, which may lead to hypothyroidism (Table 1). As mentioned above, TPO catalyzes the oxidation reactions involving the iodide ion, the iodination of $\mathrm{Tg}$, as well as the coupling of iodotyrosine residues on the Tg molecule. When TPO activity is inhibited by phenolic compounds, reducing thyroid hormone synthesis, a compensatory increase in TSH may be observed; this may lead to goiter, especially when these compounds are consumed in high quantities [28].

The flavanols quercetin, fisetin, kaempferol, morin, myricetin and rutin, present in a wide range of food sources such as kale, onions, tomatoes, cherries, apples and red wine [5, 64], together with the flavanones naringenin and naringin, can also inhibit tyrosine iodination by TPO with varying potencies. TPO inactivation by kaempferol, quercetin, naringenin and fisetin is achieved by covalent binding of reactive resorcinol radicals to catalytic amino acid radicals on TPO compound II, one of the intermediate oxidized states of the TPO enzyme formed during the coupling reactions [65]. Myricetin and naringin inhibit TPO non-competitively by different mechanisms, whereby inhibition of tyrosine iodination results from the binding of a substrate and inhibitor to different enzymatic forms or sites. They interact with TPO compound I (another oxidized intermediate, formed during both the iodination and coupling reactions), as well as with compound II, but not with native TPO or with the enzymatic iodinating TPO species (another intermediate, resulting from the reaction of compound I with iodide). On the other hand, the isoflavone biochanin A can serve as an alternative substrate for iodination; the competition between substrate and tyrosine for the enzymatic iodinating TPO species initially leads to incomplete blockade of tyrosine iodination, because the affinity for biochanin $\mathrm{A}$ is higher $[65,66]$.

The soybean-derived isoflavones genistein and daidzein, in concentrations similar to those present in the serum of subjects consuming soy derivatives, are able to inactivate TPO and to inhibit iodine organification in vitro [77]. Isoflavones can also interfere with thyroid hormone transport proteins and with 5 '-deiodinase type I (5DI) in peripheral tissues, leading to changes in thyroid hormone activity at cellular level. The enzyme 5DI catalyzes the conversion of T4 to T3, the biologically active hormone [91]. In orchidectomized middle-age rats, total serum T4 and T3 levels decreased after treatment with daidzein and genistein [74]. Besides TPO activity, discussed above, deiodination via 5DI can also be affected by baicalein, quercetin, kaempferol and rutin [69]. 
Table 1. Phenolic compounds and their effects on thyroid.

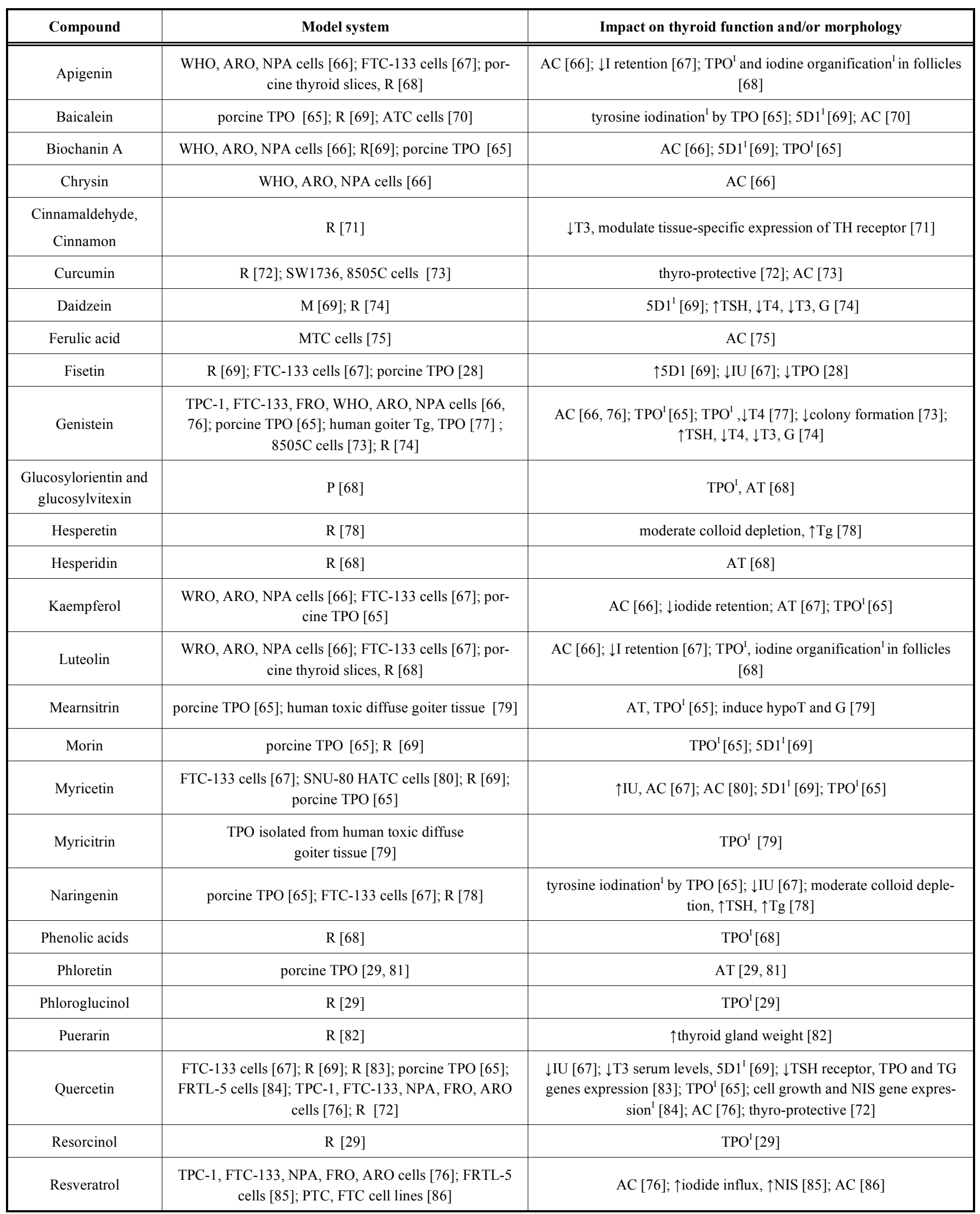




\begin{tabular}{|c|c|c|}
\hline Compound & Model system & Impact on thyroid function and/or morphology \\
\hline \hline Rottlerin & FTC cells [87] & AC [87] \\
\hline Rutin & porcine TPO [69] & TPO [69] \\
\hline Silymarin & $\mathrm{M}[88]$ & $\uparrow 5 \mathrm{D} 1, \uparrow \mathrm{T} 4, \uparrow T 3$ after carbon tetrachloride administration [88] \\
\hline Vitexin & $\mathrm{R}[68]$ & $\mathrm{TPO}^{\mathrm{I}}, \mathrm{G}, \mathrm{AT}[68]$ \\
\hline Xanthohumol & FRTL-5 cells [89]; HEK293 cells [90] & $\uparrow \mathrm{IU}[89]$; iodothyronine deiodinases ${ }^{\mathrm{I}}[90]$ \\
\hline
\end{tabular}

Effects listed in the right column and separated by semicolons have been derived from corresponding models shown in the middle column and separated by respective semicolons.

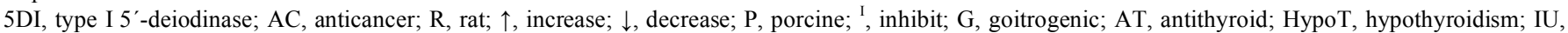
iodide uptake; TH, thyroid hormone; M, mice; ATC, anaplastic thyroid carcinoma; FTC, follicular thyroid carcinoma; PTC, papillary thyroid carcinoma; MTC, medullary thyroid carcinoma.

Hesperetin and naringenin are flavones from citrus fruits. Being potent antioxidants, they can improve the cardiovascular and metabolic status; however, they may also interfere with thyroid hormone economy. When administered to aged rats at high doses, serum TSH increased in response to naringenin treatment, while T4 remained unaltered in response to either naringenin or hesperetin treatment [78].

Quercetin is a flavonoid that is naturally abundant in a broad range of vegetables and fruits; it is also available as a dietary supplement with purported anti-inflammatory, antioxidant and antiproliferative properties. However, quercetin might carry a potential toxicity risk when consumed in excessive quantities, and it can interfere with thyroid function by inhibiting thyroid cell growth and iodide uptake. Iodide uptake inhibition is the result of downregulation of NIS gene expression [84]. Quercetin may also downregulate the expression of Tg and of the TSH receptor [83].

Besides inducing changes in thyroid function upon excessive intake, flavonoids can also have a crucial role in carcinogenesisassociated events, including invasion, kinesis modulation, apoptosis induction and cell cycle regulation. Cell culture studies have shown that flavonoids have an inhibitory effect on the proliferation of thyroid cancer cells by interfering with key enzymes in cell signaling and cell proliferation pathways, such as protein tyrosine kinase (PTK), protein kinase C (PKC), and DNA topoisomerases I and II $[92,93]$.

Apigenin, biochanin A, chrysin, genistein, luteolin and kaempferol can effectively inhibit the proliferation of cell lines derived from follicular, papillary and anaplastic thyroid carcinomas [66]. Besides inhibiting cancer initiation and progression, resveratrol, quercetin and genistein can also induce redifferentiation of thyroid cancer cells [76]. Many flavonoids inhibit thyroid cancer growth, but they also inhibit iodine uptake. Iodine uptake is not only an important step in thyroid hormone synthesis, but also a crucial exploitable mechanism for the treatment of differentiated (papillary and follicular) thyroid carcinoma with radioactive iodine. In this regard, among flavonoids thus far tested, myricetin would be an interesting modality for the treatment of thyroid carcinoma due to its capacity to increase iodide uptake and retention [67].

\subsection{Modulation of Nrf2 Activity by Phenolic Compounds}

Using in vitro and in vivo approaches, several studies have demonstrated the potential role of Nrf2 activation by phenolic compounds in the protection against oxidative stress, inflammation, cancer, and various other specific cellular toxicities, such as hepatic, cardiac and neuronal toxicities (Table 2). Of note, these studies did not focus specifically on thyroid tissue or thyroid cell lines, and therefore further research is warranted to evaluate if the described effects on the Nrf2 pathway are also applicable to the thyroid gland.
Many phenolic compounds, such as epigallocatechin-3-gallate, curcumin and catechins exert an antioxidative and antiinflammatory effect through antioxidant enzymes that are regulated by Nrf2 [159-161]. Curcumin, found in turmeric, stimulates Nrf2 transcriptional activity in a time- and dose-dependent manner, resulting in the induction of heme oxygenase 1 (HO-1) protein expression [107]. Luteolin and apigenin protect against oxidative stress through up-regulation of HO-1 and of glutamate cysteine ligase catalytic subunit via Nrf2 pathway induction [96]. The isoflavone biochanin A from cabbage, red clover and alfalfa showed antioxidative [162] and hepatoprotective effects by inducing Nrf2 nuclear translocation and up-regulation of HO-1 expression, resulting in the inhibition of oxidative liver injury induced by lipopolysaccharide in combination with D-galactosamine $\mathrm{N}$ (LPS/GalN) [101]. In a study with aged rats, treatment with hesperidin elevated the myocardial antioxidative status by lowering lipid peroxidation and protein oxidation, increasing glutathione (GSH) levels and inducing the Nrf2 pathway, which led to higher expression levels of antioxidant enzymes [122]. Morin exerts cytoprotective and genoprotective effects against oxidative stress. Morin treatment prior to $\mathrm{H}_{2} \mathrm{O}_{2}$ exposure significantly prevented the generation of ROS, increased cell viability and prevented DNA damage by up-regulating Nrf2-dependent HO-1 expression through extracellular signal-regulated kinases (ERK) in $\mathrm{C} 2 \mathrm{C} 12$ myoblasts [133]. In the case of myricetin, production of pro-inflammatory mediators through the suppression of signal transducer and activator of transcription 1 (STAT1) and Nuclear factor kappa-lightchain-enhancer of B cells (NF-kB) activation was inhibited by induction of Nrf2-mediated HO-1 expression in LPS-stimulated macrophages [134].

Interestingly, besides activating the Nrf2 pathway, some phenolic compounds can also inhibit the same pathway, with the potential therapeutic application against chemotherapy resistance. Apigenin significantly lowered $\mathrm{Nrf} 2$ expression at the protein and mRNA levels, at least partially through down-regulation of the PI3K/Akt pathway in a human papillomavirus-related endocervical adenocarcinoma cell line. Inhibition of Nrf2 by apigenin increased the intracellular concentration of doxorubicin and led to resensitization of these cells that were formerly resistant to the drug [163]. Reduction of protein and mRNA levels of Nrf2 after luteolin treatment sensitized A549 lung cancer cells to doxorubicin, potentially due to depletion of reduced glutathione resulting from down-regulation of ARE-driven genes [131]. Luteolin has also been shown to repress Nrf2 signaling in mouse livers and in A549 xenografts [132]. Hence, there is substantial mechanistic evidence that apigenin and luteolin can downregulate Nrf2 signaling by affecting Nrf2 mRNA stability [131] or modulating pathways such as PI3K [98]. This apparent discrepancy in the effects of apigenin and luteolin on the activity of the Nrf2 pathway might be due to the different models used in the various studies, or/and to some unappreciated toxic effect of these compounds on some cell lines, which could lead to 
Table 2. Phenolic compounds and their effects involving Nrf2.

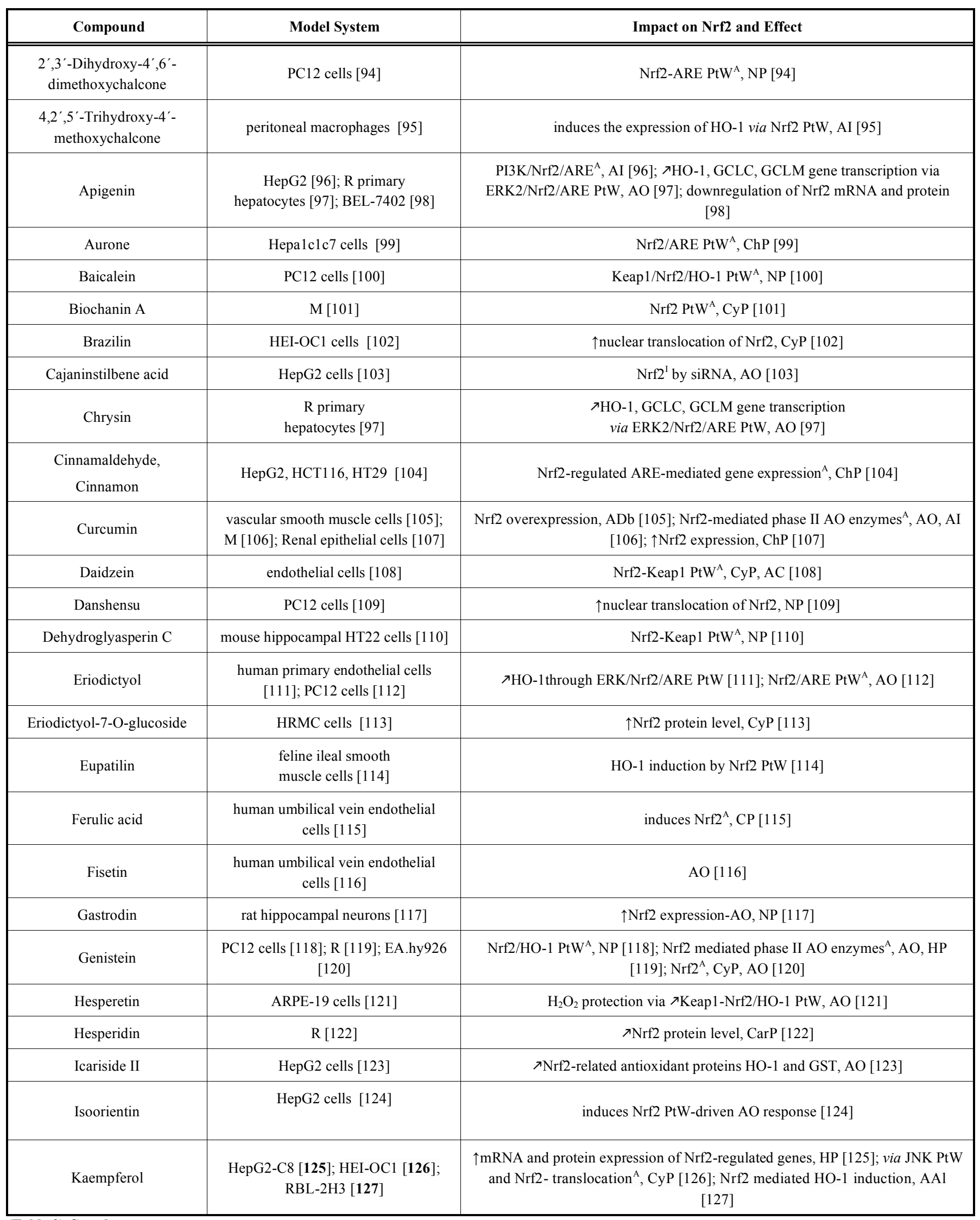




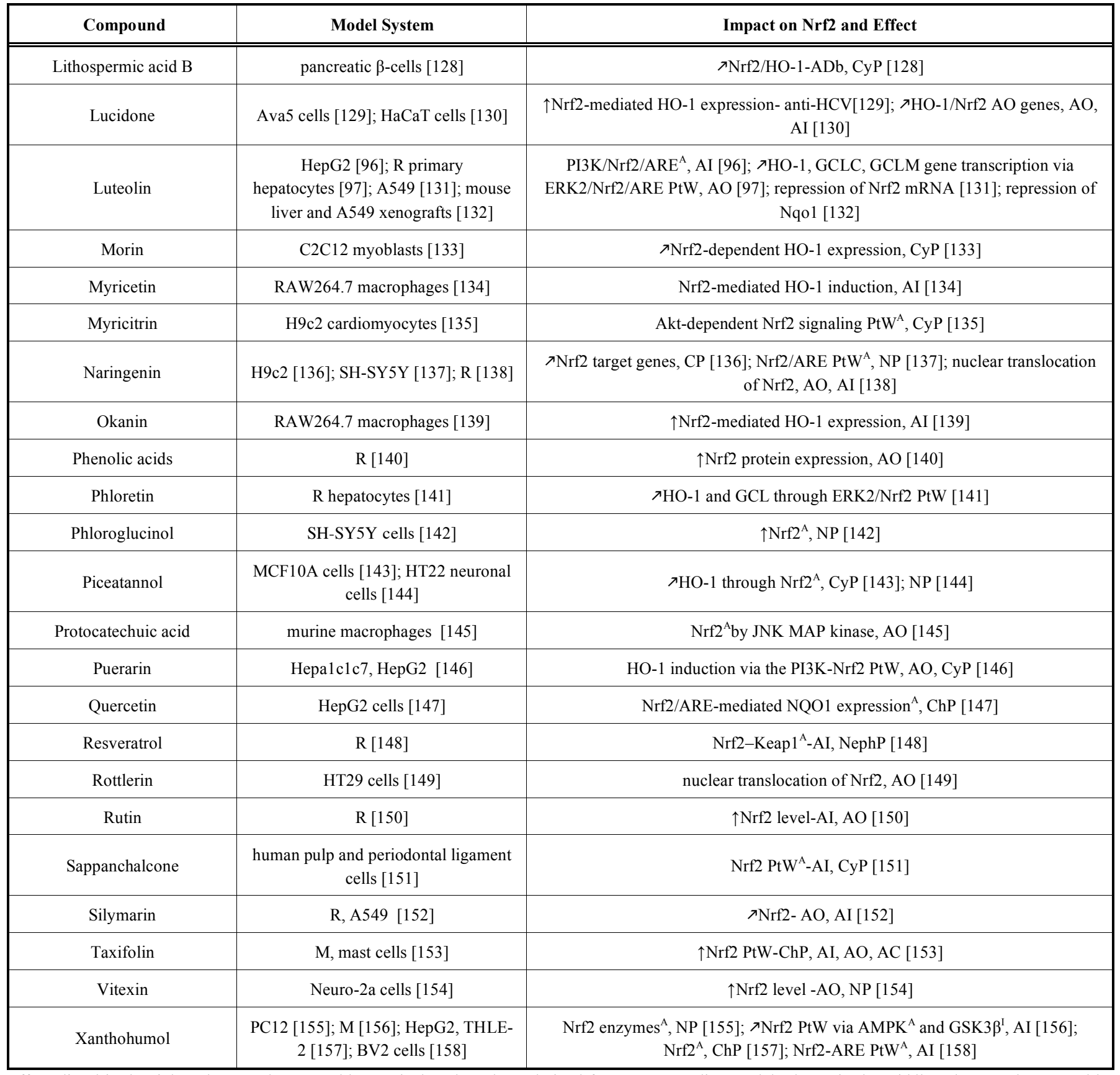

Effects listed in the right column and separated by semicolons have been derived from corresponding models shown in the middle column and separated by respective semicolons.

M, mice; R, rat; $\lambda$, up-regulate; AO, antioxidative; AI, anti-inflammatory; PtW, pathway; ${ }^{\mathrm{A}}$, activate; ${ }^{\mathrm{I}}$, inhibit; CarP, cardioprotective; ChP, chemoprotective; HO-1, heme oxygenase 1 ; PKC- $\delta$, protein kinase $\mathrm{C}$ delta; $\uparrow$, increase; $\downarrow$, decrease; P, porcine; NP, neuroprotective; CyP, cytoprotective; ERK, extracellular signal-regulated kinase; NQO1, NAD(P)H quinone dehydrogenase 1; $\gamma \mathrm{GCS}$, gamma glutamyl cysteine synthetase; AC, anticancer; NF-Kb, nuclear factor kappa-light-chain-enhancer of activated B cells; GST, glutathione S-transferase; PI3K, phosphoinositide-3-kinase; AAl, anti-allergic; ADb, antidiabetic; JNK, c-Jun N-terminal kinase; MAP, microtubule-associated protein; GCL, glutamate cysteine ligase; HCV, hepatitis C virus; GCLC, GCL catalytic subunit; GCLM, GCL modifier subunit.

secondary induction of the Nrf2 pathway. In that regard, it should be noted that the studies showing inhibition of the Nrf2 pathway are better supported by mechanistic analyses [98, 131], whereas more research is warranted to determine how it may be mechanistically possible for these compounds to also activate the Nrf2 pathway in certain settings.

\section{EFFECTS OF SULFUR-CONTAINING COMPOUNDS ON THE NRF2 PATHWAY AND ON THE THYROID}

Isothiocyanates including allyl isothiocyanate (AITC), benzyl isothiocyanate (BITC), phenethyl isothiocyanate (PEITC) and sulforaphane, from cruciferous vegetables such as brussels sprouts, broccoli, cauliflower, cabbage and watercress, are strong chemo- 
Table 3. Modulation of Nrf2 pathway and thyroid function by sulfur-containing compounds.

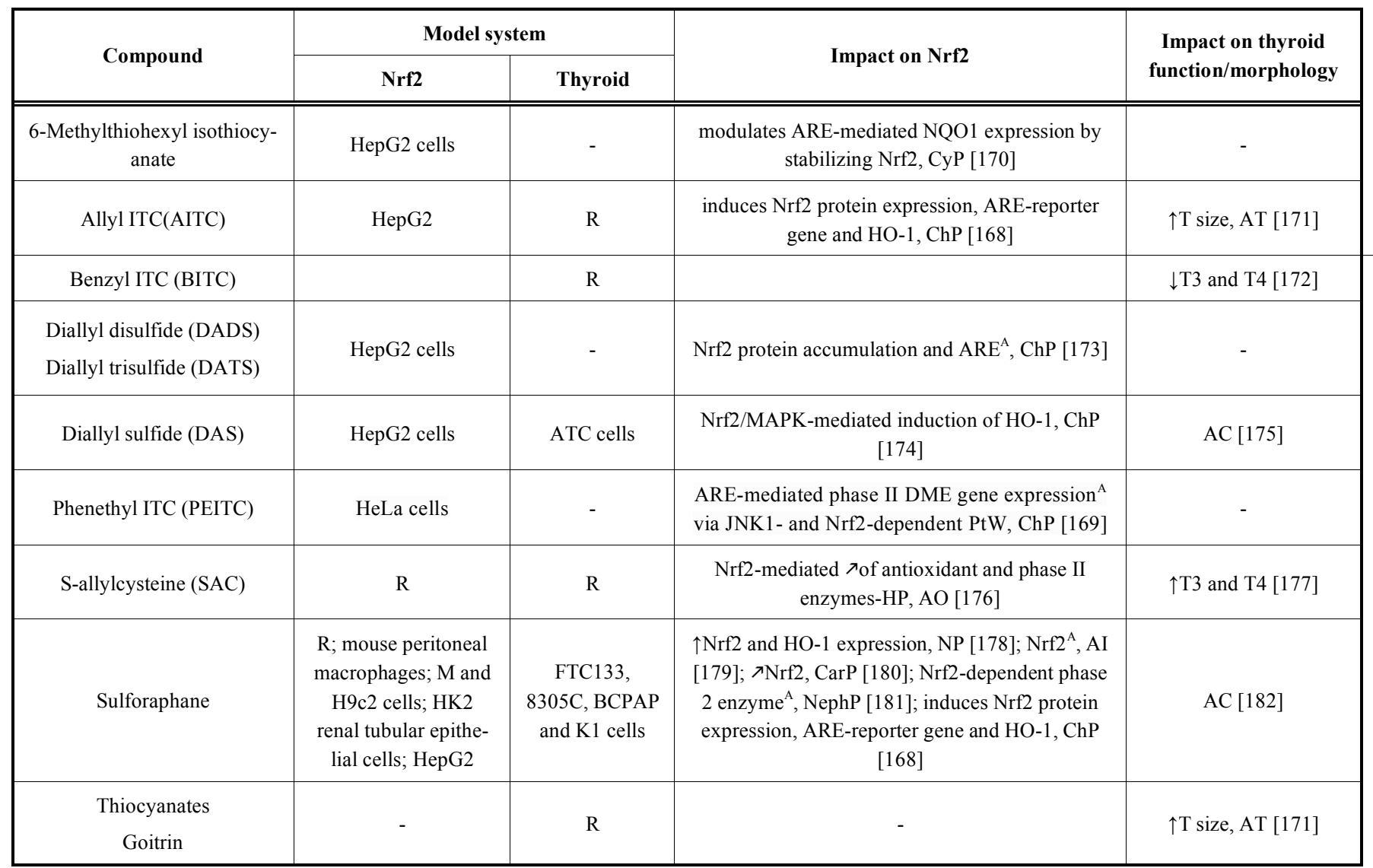

Effects listed in the fourth and fifth column and separated by semicolons have been derived from the corresponding models shown in the second and third columns, respectively, and separated by respective semicolons.

R, rat; T, thyroid; AT, antithyroid; DME, drug-metabolizing enzyme; JNK1, c-Jun N-terminal kinases; PtW, pathway; ChP, chemoprotective; HO-1, heme oxygenase 1 ; $\uparrow$, increase; NP, neuroprotective; ${ }^{\mathrm{A}}$, activate; AI, anti-inflammatory; $\nearrow$, up-regulate; CarP, cardioprotective; NephP, nephroprotective; AC, anticancer; MAPK, mitogen-activated protein kinase; HP, hepatoprotective; AO, antioxidative; NQO1, NAD(P)H quinone dehydrogenase 1; CyP, cytoprotective.

protective and anticancer agents [164]. Isothiocyanates are present in these vegetables as inactive precursors (glucosinolates), from which they are released when plant cells are damaged. Glucosinolates are converted into isothiocyanates by the enzyme myrosinase, which is also present in the human gut microflora. Exposure to antibiotics that alter the microflora can largely reduce the conversion of glucosinolates into isothiocyanates [165]. The bioavailability of isothiocyanates is also affected by diurnal variations, with higher conversion of glucosinolates to dithiocarbamates during the day, and higher conversion of isothiocyanates to dithiocarbamates during night [166]. Isothiocyanates induce cytoprotective proteins via the Nrf2/Keap1/ARE pathway, thus conferring protection against oxidants and electrophiles and thereby potentially exerting chemopreventive and/or therapeutic actions against a wide range of diseases [167].

Sulforaphane and AITC treatment in hepatocellular carcinoma HepG2 cells potently induced HO-1 protein expression via Nrf2 pathway induction (Table 3). PEITC can also induce the protein expression levels of Nrf2 and HO-1 by stimulating ARE-mediated transcription in Hela cells $[168,169]$.

Diallyl sulfides from onion, chive and garlic, such as diallyl sulfide (DAS), diallyl disulfide (DADS), and diallyl trisulfide (DATS), can also act as potential chemoprotective agents. Diallyl sulfides can affect the expression of Nrf2, HO-1, NAD(P)H quinone dehydrogenase 1 (NQO1) and other proteins encoded by ARE-regulated genes. For example, DAS induces HO-1 through the production of
ROS, and this induction is mediated by Nrf2 and mitogen-activated protein kinases (MAPK), while DADS and DATS induce glutathione reductase, glutathione S-transferases, ferritin and NQO1 in cultured cells and in animals [173, 174, 183-185].

Sulfur-containing compounds can modulate thyroid function and might be efficacious in inhibiting thyroid cancer progression. Through an ROS-dependent pathway, sulforaphane inhibits thyroid cancer cell proliferation, invasion and migration, and it induces cell cycle arrest without significant toxicities such as liver injury, which makes it a potentially effective and safe modality for cancer treatment [182]. In many animal models, DAS inhibits chemicallyinduced carcinogenesis. For example, treatment of the anaplastic thyroid cancer cell line ARO with DAS inhibited proliferation by increasing in a dose-dependent manner, the accumulation of sub-G1 DNA and the associated accumulation of cells in the G2/M phase via mitochondrial signaling pathways [175].

BITC, which has been extensively used as a chemopreventive agent, has been shown to decrease total T4 and T3 levels in rats after two weeks of daily treatment at doses known to have anticarcinogenic effects [172].

In another study, rats were fed with a combination of goitrin, a sulfur-containing oxazolidine, thiocyanate and AITC, in concentrations comparable to those present in the daily amount of cabbage that these rats can consume, and this treatment resulted in increased thyroid size. This effect could not be reproduced by administering individually any of these compounds, meaning that only their com- 
bination, as found in cabbage, can lead to increased thyroid size [186]. Of note, in a recent randomized clinical trial, we showed that daily administration of a sulforaphane-rich broccoli sprout extract to healthy volunteers did not have any detrimental effect on thyroid function or the thyroid autoimmunity status [187].

The most abundant sulfur-containing compound from garlic, Sallylcysteine (SAC), has a potential beneficial effect in diabetes. In streptozotocin-induced diabetic rats, TSH and thyroid hormone levels decreased, along with circulating catalase (CAT), GSH, glutathione peroxidase (GPx), superoxide dismutase (SOD) and insulin levels. Treatment with SAC reversed these effects and could be used to restore antioxidant capacity, reduce lipid peroxidation and preserve thyroid function in diabetic subjects [177].

\section{QUINONES AND TERPENOIDS}

Quinones and terpenoids, including mono-, di-, tri-, and sesquiterpenoids, are organic compounds with high diversity in structure and bioactivity (Table 4). Even though many reports demonstrate that these compounds can activate the Nrf2 pathway, their potential effects on thyroid physiology and disease are rarely examined. In view of the highly variable chemical structures and biological activities of quinones and terpenoids, further research of their actions on the thyroid could give interesting insights into potential beneficial and/or detrimental effects.

\section{PLANT EXTRACTS AND THYROID}

Extracts from plants and medical herbs, even though they may contain several compounds in variable and unstandardized concentrations, comprise a rich source of candidate drugs that may have potential effects on thyroid gland function (Table 5).

Medical herbs such as Lycopus americanus, Lycopus europaeus, Lycopus virginicus arious, Lithospermum officinale and Lithospermum ruderale show promising potential for the treatment of hyperthyroidism, while Plectranthus barbatus, Withania somnifera, Centella asiatica and Commiphora mukul might be useful to treat hypothyroidism. Interestingly, withaferin A, which is contained in Withania somnifera, has recently been shown to be a potent inducer of the Nrf2 pathway [215]. Treatment for hyperthyroidism and hypothyroidism with herb extracts can have variable effects and may be sufficient for treating symptoms in some cases, but at the present state of knowledge, it should not be used in the place of established conventional treatment, especially for serious thyroid disorders [216].

Boiled extracts of cassava, bamboo shoot, cauliflower and cabbage can inhibit TPO activity [217]. Kalanchoe brasiliensis aqueous extract can also inhibit TPO, and experiments with this extract showed that chronic consumption combined with low iodine intake can cause hypothyroidism and goiter [218]. In mice, leaf extracts of Aegle marmelos, Bacopa monnieri and Aloe vera can alter thyroid hormone concentrations. Aloe vera and Aegle marmelos decreased T3 concentration and could thus provide a beneficial effect in the treatment of hyperthyroidism, whereas Bacopa monnieri increased T4 concentration and could be useful for the treatment of hypothyroidism [219].

Rats treated with green and black tea extract rich in catechins showed decreased T3 and T4 serum levels as well as decreased 5DI and TPO activity, while $\mathrm{Na}+/ \mathrm{K}+-\mathrm{ATPase}$ activity was increased along with TSH levels. Treatment also led to hypertrophy and/or hyperplasia of thyroid follicles, with reduced colloid content [220].

Plant extracts can also provide potential new approaches in thyroid cancer treatment. Aglaia coriacea, Aglaia gracilis, Aglaia elaeagnoidea, Aglaia edulis, Aglaia odorata, and Stemona tuberosa extracts inhibited the proliferation of medullary thyroid carcinoma cell lines. Aglaia basiphylla, Aglaia basiphylla, Aglaia tenuicaulis and Stemona collinsae extracts had antiproliferative effects, whereas apoptotic effects were seen in cells treated with Stemona tuberosa extract [221].

\section{OTHER COMPOUNDS MODULATING NRF2 PATHWAY AND THYROID FUNCTION}

Apart from the aforementioned categories of phytochemicals, other naturally occurring compounds can also activate the Nrf2 pathway and affect thyroid function; these are listed in Table 6.

\section{CONCLUSION}

The use of phytochemicals from edible plants may provide a sustainable and effective solution for the treatment and prevention of diseases, with potential clinical utility both in underdeveloped countries that still do not have access to expensive medications, as well as in developed countries challenged by increasing healthcare costs and/or endorsing complementary medicine. Food-derived phytochemicals with cytoprotective and antioxidant properties have already been tested for potential use in a wide range of diseases, including cardiac and psychiatric disorders, diabetes, viral, microbial and parasitic infections, inflammation and cancer. However, little is known about the impact of phytochemicals on thyroid function and the potential underlying modulation of the Nrf2 pathway, an important mediator of antioxidant, cytoprotective and other effects in cells. We and others have recently shown the importance of the Nrf2 pathway in the thyroid gland; Nrf2 not only coordinates the antioxidant response under basal and iodide excess conditions, but it also regulates the transcription of the $\mathrm{Tg}$ gene itself, and it further affects the iodination of $\mathrm{Tg}$ under various conditions [43]. Thus, the Nrf2 pathway can potentially integrate the protection of thyroid cells from excessive ROS production with the regulation of thyroid function through $\mathrm{Tg}$ gene transcription and $\mathrm{Tg}$ iodination $[30,48]$.

The present literature review identified several categories of phytochemicals that may have an impact on thyroid physiology and disease, and discussed their potential effects on the Nrf2 pathway. Reports that address the effects of specific phytochemicals on both the thyroid and the activity of Nrf2 are rather few; therefore, we also included studies using other tissues/cell lines to provide insights into whether a certain phytochemical's effects on the thyroid may be derived from its potential to modulate the Nrf2 pathway. Figure 1 briefly summarizes the potential effects of these compounds on thyroid gland function and physiology.

In summary, there are phytochemicals with known antioxidant or other cytoprotective properties that have shown promising results in the field of cancer prevention, but may have a detrimental effect on thyroid function at certain doses or in certain combinations. Thus, caution should be exercised when drawing conclusions about the potential beneficial or detrimental effects of a phytochemical on thyroid function, and this issue should be carefully characterized, including via classical toxicology approaches. While the health benefits associated with natural compounds found in plants in low amounts are generally well accepted, attention should be drawn to potential toxicities arising from the use of concentrated extracts that may contain excess amounts of phytochemicals. For instance, a daily dose of $600 \mu \mathrm{mol}$ glucoraphanin and $40 \mu \mathrm{mol}$ sulforaphane in the form of broccoli sprout extracts over 12 weeks has been shown to be effective against the detoxification of airborne pollutants [234], and this dosing scheme was proven to be safe for the thyroid [187]. 
Table 4. Modulation of Nrf2 pathway and thyroid function by quinones and terpenoids.

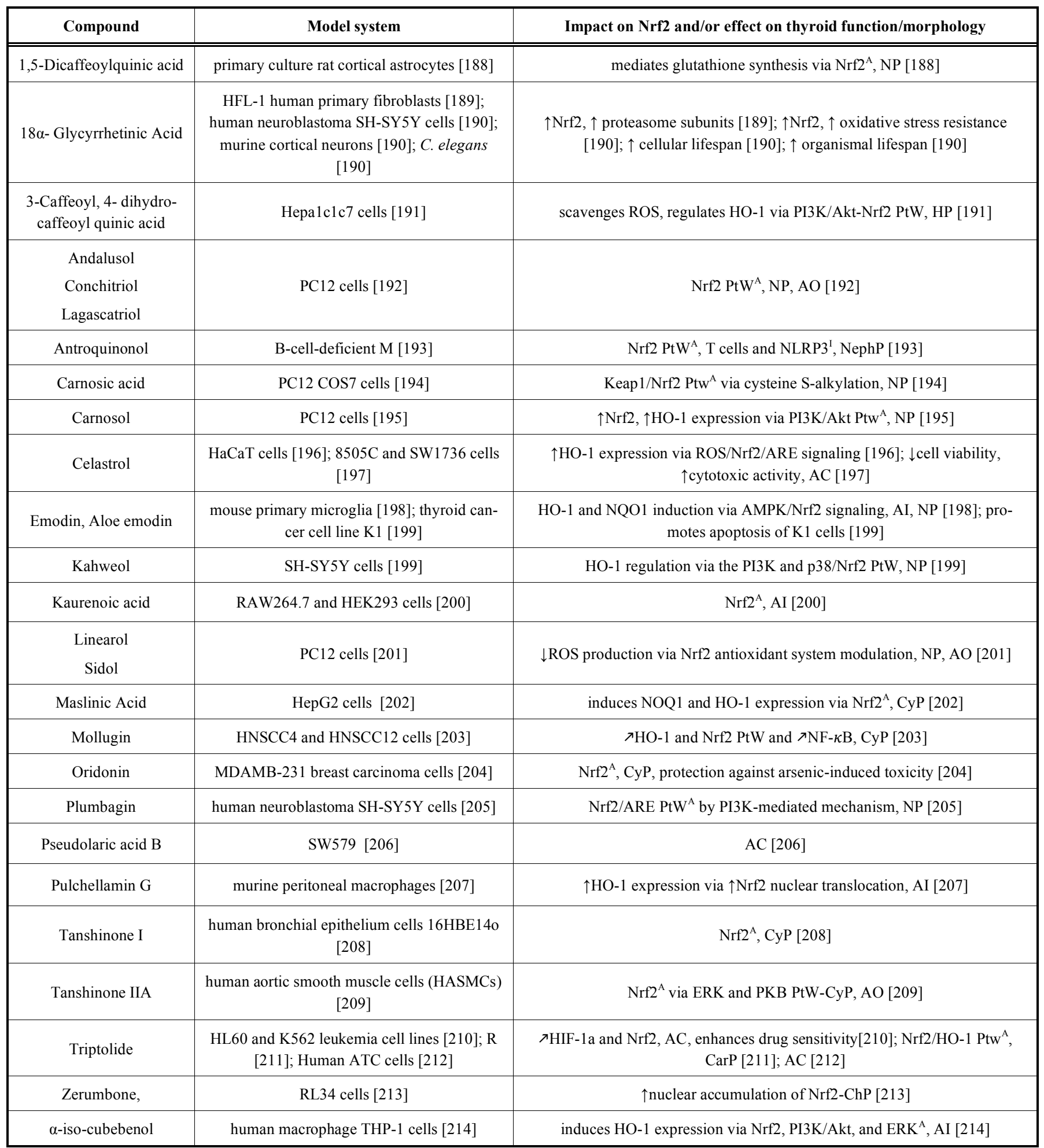

HO-1, heme oxygenase 1; NQO1, NAD(P)H quinone dehydrogenase 1; AMPK, 5' AMP-activated protein kinase; AI, anti-inflammatory; NP, neuroprotective; ROS, reactive oxygen species; $\uparrow$, increase; $\downarrow$, decrease; AC, anticancer; PI3K, phosphoinositide-3-kinase; Akt/PKB, protein kinase B; PtW, pathway; HP, hepatoprotective; ERK, extracellular signal-regulated kinase; CyP, cytoprotective; AO, antioxidative; $\lambda$, up-regulate; NF-kB, nuclear factor kappa-light-chainenhancer of activated B cells; NLRP3, the NLR family, pyrin domain-containing 3 inflammasome; ' , inhibit; NephP, nephroprotective; HIF-1a, hypoxiainducible factor 1-alpha; CarP, cardioprotective; ${ }^{\mathrm{A}}$, activate. 
Table 5. Plant extracts with potential clinical utility and their respective effects on the thyroid gland.

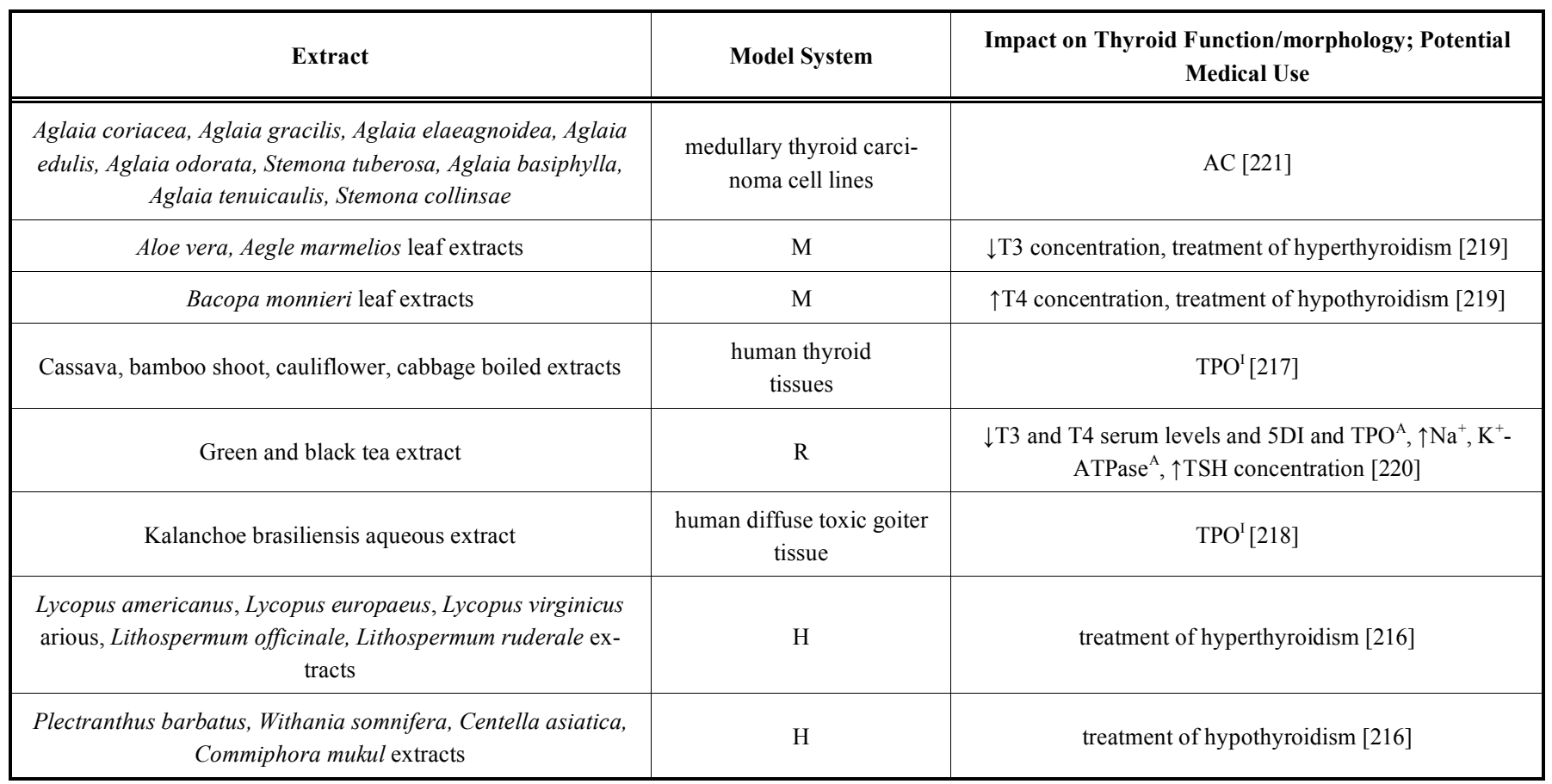

$\mathrm{H}$, human; ${ }^{\mathrm{I}}$, inhibit; $^{\mathrm{A}}$, activate; $\uparrow$, increase; $\downarrow$, decrease; 5DI, type I $5^{\prime}$-deiodinase; AC, anticancer.

Table 6. Other natural compounds with ability to modulate Nrf2 activity and potentially affect thyroid function.

\begin{tabular}{|c|c|c|}
\hline Compound & Model system & Impact on Nrf2 and effect \\
\hline 3 -hydroxy - $\beta$-damascone & Hepa 1c1c7 murine hepatoma cells & Nrf2-dependent induction of phase 2 DMEs, AC [222] \\
\hline Ankaflavin & MG-induced R & Nrf2 phosphorylation, $\mathrm{HO}-1$ and $\mathrm{GCL}^{\mathrm{A}}, \mathrm{AO}, \mathrm{ADb}[224]$ \\
\hline Eckol & Chinese hamster lung fibroblast (V79-4) & $\pi \mathrm{Nrf2}$-mediated HO-1 expression via ERK and PI3K/AKT PtW, CyP [225] \\
\hline Forsythiaside A & BV2 microglia cells & Nrf2/HO-1 ${ }^{\mathrm{A}} \mathrm{PtW},{ }^{\mathrm{N} r f 2}$ and HO-1 expression, NF-kB ${ }^{\mathrm{I}}, \mathrm{AI}[227]$ \\
\hline Fucoxanthin & murine hepatic BNL CL.2 Cells & $\begin{array}{l}\uparrow \mathrm{HO}-1 \text { and NQO1 mRNA and protein expression via Nrf2/ARE } \mathrm{PtW}^{\mathrm{A}} \text {, pro- } \\
\text { oxidant activity [228] }\end{array}$ \\
\hline Gymnasterkoreayne B & HCT116 human colon cancer cells & induces NQO-1 and Nrf2 translocation via ERK and PKC PtW, ChP [229] \\
\hline Schisandrin B & $\mathrm{H} 9 \mathrm{c} 2$ cells & ERK/Nrf2 ${ }^{\mathrm{A}} \mathrm{PtW}, \mathrm{AO}, \mathrm{CyP}[232]$ \\
\hline Triphlorethol A & Chinese hamster lung fibroblast (V79-4) & $\lambda \mathrm{HO}-1$ gene expression via Nrf2 and $\mathrm{ERK}^{\mathrm{A}}, \mathrm{CyP}, \mathrm{AO}[233]$ \\
\hline
\end{tabular}

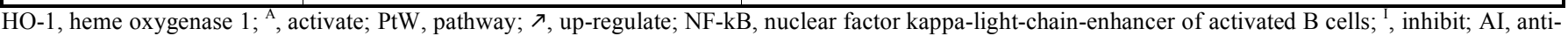
inflammatory; GST, glutathione S-transferase; $\gamma \mathrm{GCS}$, gamma glutamyl cysteine synthetase; ERK, extracellular signal-regulated kinase; AO, antioxidative; CyP, cytoprotective; PKC- $\delta$, protein kinase C delta; GSK3 $\beta$, glycogen synthase kinase 3 beta; HP, hepatoprotective; DMEs, drug-metabolizing enzymes; PKC, protein kinase $\mathrm{C}$; $\mathrm{ChP}$, chemoprotective; MG, methylglyoxal; GCL, glutamate-cysteine ligase; ADb, antidiabetic; AC, anticancer; $\uparrow$, increase; NQO1, $\mathrm{NAD}(\mathrm{P}) \mathrm{H}$ quinone dehydrogenase 1.

To conclude, this review catalogues the phytochemicals that may have an effect on the thyroid gland and on the Nrf2 pathway, and it conveys the message that each dietary supplement intended for human use that contains such phytochemicals, should be carefully evaluated in this aspect, first by analyzing its contents, and then by assessing its potential effects on thyroid function. Such diligence will contribute to realizing the promise of the old yet highly active field of "chemoprevention" against diseases via natural compounds, aiming to propose novel treatments by identifying 


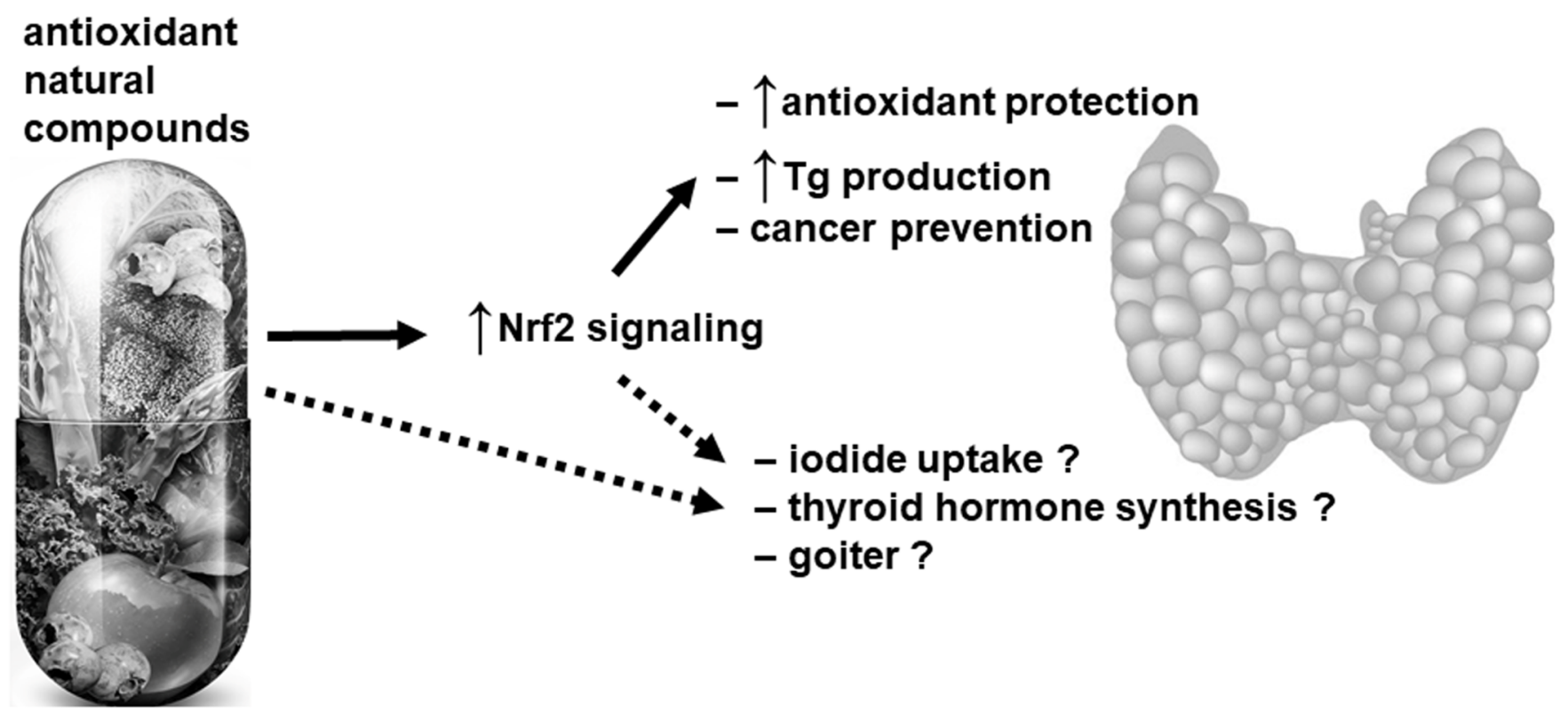

Fig. (1). Simplified model summarizing the potential effects that antioxidant natural compounds can have on thyroid physiology through Nrf2-dependent and Nrf2-independent pathways. Antioxidant natural compounds (phenolic compounds, sulfur-containing compounds, quinones, terpenoids and diverse plant extracts) have the potential to upregulate Nrf2 signaling through various mechanisms. The induction of Nrf2 signaling exerts antioxidant cytoprotective functions, upregulates the expression of thyroglobulin ( $\mathrm{Tg}$ ) and has potential cancer-preventing effects (indicated by solid arrows). These natural compounds have also been described to impact iodide uptake, thyroid hormone synthesis and thyroid size (goiter); the mechanisms of these latter effects are less clearly specified (indicated by dashed arrows), and the potential involvement of $\mathrm{Nrf} 2$ has not been well documented. Research is thus warranted especially in animal models and humans to further elucidate these mechanisms.

new, cost-efficient and safe therapeutic agents to promote public health.

\section{CONSENT FOR PUBLICATION}

Not applicable.

\section{FUNDING}

This work was supported by the Swiss National Science Foundation Research Grants 31003A_153062 and 31003A_182105; Leenaards Foundation 2016 Fellowship for Academic Promotion in Clinical Medicine; Swiss National Science Foundation - State Secretariat for Education, Research and Innovation (SNF-COST) Project 174626 - C15.0045; and SNF COST Project IZCOZ0_177070 (all to GPS).

\section{CONFLICT OF INTEREST} wise.

The authors declare no conflict of interest, financial or other-

\section{ACKNOWLEDGEMENTS}

The work benefited from COST Action CA16112 (NutRedOx), supported by European Cooperation in Science and Technology (COST) (participants: DVC, NC, GPS), including a Short-Term Scientific Mission (to DVC).

\section{REFERENCES}

[1] Hines E. New nutritive substances: Beyond the ABCs. Food Quality $1999 ; 6: 39-43$.

[2] Willett WC. Diet, nutrition, and avoidable cancer. Environ Health Perspect 1995; 103(Suppl. 8): 165-70. [PMID: 8741778]

[3] Temple NJ. Antioxidants and disease: more questions than answers. Nutr Res 2000; 20: 449-59.
[http://dx.doi.org/10.1016/S0271-5317(00)00138-X]

[4] Willett WC. Diet and health: what should we eat? Science 1994; 264(5158): 532-7.

[http://dx.doi.org/10.1126/science.8160011] [PMID: 8160011]

[5] Liu RH. Health benefits of fruit and vegetables are from additive and synergistic combinaions of phytochemicals. Am J Clin Nutr 2003; 78: 3-6.

[http://dx.doi.org/10.1093/ajcn/78.3.517S]

[6] Dinkova-Kostova AT, Talalay P. Direct and indirect antioxidant properties of inducers of cytoprotective proteins. Mol Nutr Food Res 2008; 52(Suppl. 1): S128-38.

[http://dx.doi.org/10.1002/mnfr.200700195] [PMID: 18327872]

[7] Skibola CF, Smith MT. Potential health impacts of excessive flavonoid intake. Free Radic Biol Med 2000; 29(3-4): 375-83. [http://dx.doi.org/10.1016/S0891-5849(00)00304-X] [PMID: 11035267]

[8] Sykiotis GP, Bohmann D. Stress-activated cap'n'collar transcription factors in aging and human disease. Sci Signal 2010; 3(112): re3.

[http://dx.doi.org/10.1126/scisignal.3112re3] [PMID: 20215646]

[9] Yamamoto M, Kensler TW, Motohashi H. The KEAP1-NRF2 System: a Thiol-Based Sensor-Effector Apparatus for Maintaining Redox Homeostasis. Physiol Rev 2018; 98(3): 1169-203. [http://dx.doi.org/10.1152/physrev.00023.2017] [PMID: 29717933]

[10] Suzuki T, Yamamoto M. Molecular basis of the Keap1-Nrf2 system. Free Radic Biol Med 2015; 88(Pt B): 93-100.

[http://dx.doi.org/10.1016/j.freeradbiomed.2015.06.006] [PMID: 26117331]

[11] Yamamoto T, Suzuki T, Kobayashi A, et al. Physiological significance of reactive cysteine residues of Keap1 in determining Nrf2 activity. Mol Cell Biol 2008; 28(8): 2758-70.

[http://dx.doi.org/10.1128/MCB.01704-07] [PMID: 18268004]

[12] Kwak MK, Wakabayashi N, Greenlaw JL, Yamamoto M, Kensler TW. Antioxidants enhance mammalian proteasome expression through the Keap1-Nrf2 signaling pathway. Mol Cell Biol 2003; 23(23): 8786-94.

[http://dx.doi.org/10.1128/MCB.23.23.8786-8794.2003] [PMID: 14612418] 
[13] Saito R, Suzuki T, Hiramoto K, et al. Characterizations of Three Major Cysteine Sensors of Keap1 in Stress Response. Mol Cell Biol 2015; 36(2): 271-84.

[http://dx.doi.org/10.1128/MCB.00868-15] [PMID: 26527616]

[14] Zhang Y, Talalay P, Cho CG, Posner GH. A major inducer of anticarcinogenic protective enzymes from broccoli: isolation and elucidation of structure. Proc Natl Acad Sci USA 1992; 89(6): 2399403 .

[http://dx.doi.org/10.1073/pnas.89.6.2399] [PMID: 1549603]

[15] Dinkova-Kostova AT, Holtzclaw WD, Cole RN, et al. Direct evidence that sulfhydryl groups of Keapl are the sensors regulating induction of phase 2 enzymes that protect against carcinogens and oxidants. Proc Natl Acad Sci USA 2002; 99(18): 11908-13. [http://dx.doi.org/10.1073/pnas.172398899] [PMID: 12193649]

[16] Egner PA, Chen JG, Wang JB, et al. Bioavailability of Sulforaphane from two broccoli sprout beverages: results of a short-term, cross-over clinical trial in Qidong, China. Cancer Prev Res (Phila) 2011; 4(3): 384-95.

[http://dx.doi.org/10.1158/1940-6207.CAPR-10-0296] [PMID: 21372038]

[17] Dinkova-Kostova AT, Fahey JW, Kostov RV, Kensler TW. KEAP1 and Done? Targeting the NRF2 Pathway with Sulforaphane. Trends Food Sci Technol 2017; 69(Pt B): 257-69.

[http://dx.doi.org/10.1016/j.tifs.2017.02.002] [PMID: 29242678]

[18] Kensler TW, Ng D, Carmella SG, et al. Modulation of the metabolism of airborne pollutants by glucoraphanin-rich and sulforaphanerich broccoli sprout beverages in Qidong, China. Carcinogenesis 2012; 33(1): 101-7.

[http://dx.doi.org/10.1093/carcin/bgr229] [PMID: 22045030]

[19] Axelsson AS, Tubbs E, Mecham B, et al. Sulforaphane reduces hepatic glucose production and improves glucose control in patients with type 2 diabetes. Sci Transl Med 2017; 9(394): 9.

[http://dx.doi.org/10.1126/scitranslmed.aah4477] [PMID: 28615356]

[20] Singh K, Connors SL, Macklin EA, et al. Sulforaphane treatment of autism spectrum disorder (ASD). Proc Natl Acad Sci USA 2014; 111(43): 15550-5.

[http://dx.doi.org/10.1073/pnas.1416940111] [PMID: 25313065]

[21] Surh YJ, Kundu JK, Na HK. Nrf2 as a master redox switch in turning on the cellular signaling involved in the induction of cytoprotective genes by some chemopreventive phytochemicals. Planta Med 2008; 74(13): 1526-39.

[http://dx.doi.org/10.1055/s-0028-1088302] [PMID: 18937164]

[22] Chaker L, Bianco AC, Jonklaas J, Peeters RP. Hypothyroidism. Lancet 2017; 390(10101): 1550-62.

[http://dx.doi.org/10.1016/S0140-6736(17)30703-1] [PMID: 28336049]

[23] Hollowell JG. academic.oup.com NWSJoC, undefined. Serum TSH, T4, and Thyroid Antibodies in the United States Population (1988 to 1994): National Health and Nutrition Examination Survey (NHANES III). academic.oup.com

[24] McLeod DSA, Cooper DS. The incidence and prevalence of thyroid autoimmunity. Endocrine 2012; 42(2): 252-65.

[http://dx.doi.org/10.1007/s12020-012-9703-2] [PMID: 22644837]

[25] Faggiano A, Del Prete M, Marciello F, Marotta V, Ramundo V, Colao A. Thyroid diseases in elderly. Minerva Endocrinol 2011; 36(3): 211-31.

[PMID: 22019751]

[26] Tabatabaie V, Surks MI. The aging thyroid. Curr Opin Endocrinol Diabetes Obes 2013; 20(5): 455-9.

[http://dx.doi.org/10.1097/01.med.0000433055.99570.52] [PMID: 23974775]

[27] Hurley DL, Gharib H. Evaluation and management of multinodular goiter. Otolaryngol Clin North Am 1996; 29(4): 527-40. [PMID: 8844728]

[28] Divi RL, Doerge DR. Mechanism-based inactivation of lactoperoxidase and thyroid peroxidase by resorcinol derivatives. Biochemistry $1994 ; 33(32)$ : 9668-74.

[http://dx.doi.org/10.1021/bi00198a036] [PMID: 8068644]

[29] Gaitan E. Flavonoids and the thyroid. Nutrition 1996; 12(2): 127-9. [http://dx.doi.org/10.1016/S0899-9007(97)85052-7] [PMID: 8724387]

[30] Kopp P. Thyroid hormone synthesis. In: Braverman LE, Utiger RD, ed.^eds. Lippincott Williams \& Wilkins: Philadelphia, USA, 2005; pp. 48-74.
[31] Carvalho DP, Dupuy C. Thyroid hormone biosynthesis and release. Mol Cell Endocrinol 2017; 458: 6-15.

[http://dx.doi.org/10.1016/j.mce.2017.01.038] [PMID: 28153798]

[32] Scott DA, Wang R, Kreman TM, Sheffield VC, Karniski LP. The Pendred syndrome gene encodes a chloride-iodide transport protein. Nat Genet 1999; 21(4): 440-3.

[http://dx.doi.org/10.1038/7783] [PMID: 10192399]

[33] Gillam MP, Sidhaye AR, Lee EJ, Rutishauser J, Stephan CW, Kopp P. Functional characterization of pendrin in a polarized cell system. Evidence for pendrin-mediated apical iodide efflux. J Biol Chem 2004; 279(13): 13004-10.

[http://dx.doi.org/10.1074/jbc.M313648200] [PMID: 14715652]

[34] Silveira JC, Kopp PA. Pendrin and anoctamin as mediators of apical iodide efflux in thyroid cells. Curr Opin Endocrinol Diabetes Obes 2015; 22(5): 374-80.

[http://dx.doi.org/10.1097/MED.0000000000000188] [PMID: 26313899]

[35] Massart C, Hoste C, Virion A, Ruf J, Dumont JE, Van Sande J Cell biology of $\mathrm{H} 2 \mathrm{O} 2$ generation in the thyroid: investigation of the control of dual oxidases (DUOX) activity in intact ex vivo thyroid tissue and cell lines. Mol Cell Endocrinol 2011; 343(1-2): 32-44. [http://dx.doi.org/10.1016/j.mce.2011.05.047] [PMID: 21683758]

[36] Rousset B, Dupuy C, Miot F, Dumont J. Chapter 2 Thyroid Hormone Synthesis And Secretion. MDText.com, Inc. 2000

[37] Dunn AD, Crutchfield HE, Dunn JT. Proteolytic processing of thyroglobulin by extracts of thyroid lysosomes. Endocrinology 1991; 128(6): 3073-80.

[http://dx.doi.org/10.1210/endo-128-6-3073] [PMID: 1903699]

[38] Dunn AD, Crutchfield HE, Dunn JT. Thyroglobulin processing by thyroidal proteases. Major sites of cleavage by cathepsins B, D, and L. J Biol Chem 1991; 266(30): 20198-204.

[PMID: 1939080]

[39] Gnidehou S, Caillou B, Talbot M, et al. Iodotyrosine dehalogenase 1 (DEHAL1) is a transmembrane protein involved in the recycling of iodide close to the thyroglobulin iodination site. FASEB J 2004; 18(13): 1574-6.

[http://dx.doi.org/10.1096/fj.04-2023fje] [PMID: 15289438]

[40] Poncin S, Colin IM, Gérard AC. Minimal oxidative load: a prerequisite for thyroid cell function. J Endocrinol 2009; 201(1): 161-7. [http://dx.doi.org/10.1677/JOE-08-0470] [PMID: 19168506]

[41] Poncin S, Eeckoudt SV, Humblet K. IMCTAjo, undefined. Oxidative stress: a required condition for thyroid cell proliferation. Elsevier

[42] Poncin S, Gerard AC, Boucquey M. IMCTAjo, undefined. Oxidative stress: a required condition for thyroid cell proliferation. Elsevier academic.oup.com

[43] Ziros PG, Habeos IG, Chartoumpekis DV, et al. NFE2-Related Transcription Factor 2 Coordinates Antioxidant Defense with Thyroglobulin Production and Iodination in the Thyroid Gland. Thyroid $2018 ; 28(6): 780-98$.

[http://dx.doi.org/10.1089/thy.2018.0018] [PMID: 29742982]

[44] Maier J, van Steeg H, van Oostrom C, Paschke R, Weiss RE, Krohn K. Iodine deficiency activates antioxidant genes and causes DNA damage in the thyroid gland of rats and mice. Biochim Biophys Acta 2007; 1773(6): 990-9.

[http://dx.doi.org/10.1016/j.bbamcr.2007.03.011] 17467074]

[45] Krohn K, Maier J, Paschke R. Mechanisms of disease: hydrogen peroxide, DNA damage and mutagenesis in the development of thyroid tumors. Nat Clin Pract Endocrinol Metab 2007; 3(10): 71320.

[http://dx.doi.org/10.1038/ncpendmet0621] [PMID: 17893690]

[46] Leoni SG, Kimura ET, Santisteban P, De la Vieja A. Regulation of thyroid oxidative state by thioredoxin reductase has a crucial role in thyroid responses to iodide excess. Mol Endocrinol 2011; 25(11): 1924-35.

[http://dx.doi.org/10.1210/me.2011-0038] [PMID: 21903721]

[47] Poncin S, Gérard A-C, Boucquey M, et al. Oxidative stress in the thyroid gland: from harmlessness to hazard depending on the iodine content. Endocrinology 2008; 149(1): 424-33.

[http://dx.doi.org/10.1210/en.2007-0951] [PMID: 17884933]

[48] Di Jeso B, Arvan P. Thyroglobulin From Molecular and Cellular Biology to Clinical Endocrinology. Endocr Rev 2016; 37(1): 2-36. [http://dx.doi.org/10.1210/er.2015-1090] [PMID: 26595189] 
[49] Leonard JL, Korhle J. Intracellular pathways of iodothyronine metabolism. The Thyroid-A Fundamental and Clinical Text, seventh ed. Philadelphia, USA 1996.

[50] Wakabayashi N, Chartoumpekis DV, Kensler TW. Crosstalk between Nrf2 and Notch signaling. Free Radic Biol Med 2015; 88(Pt B): 158-67.

[http://dx.doi.org/10.1016/j.freeradbiomed.2015.05.017] [PMID: 26003520]

[51] Chartoumpekis DV, Kensler TW. New player on an old field; the keap1/Nrf2 pathway as a target for treatment of type 2 diabetes and metabolic syndrome. Curr Diabetes Rev 2013; 9(2): 137-45.

[http://dx.doi.org/10.2174/1573399811309020005] [PMID: 23363332]

[52] Sellitti DF, Suzuki K. Intrinsic regulation of thyroid function by thyroglobulin. Thyroid 2014; 24(4): 625-38 [http://dx.doi.org/10.1089/thy.2013.0344] [PMID: 24251883]

[53] Ferrandino G, Kaspari RR, Reyna-Neyra A, Boutagy NE, Sinusas AJ, Carrasco N. An extremely high dietary iodide supply forestalls severe hypothyroidism in $\mathrm{Na}^{+} / \mathrm{I}^{-}$symporter (NIS) knockout mice. Sci Rep 2017; 7(1): 5329.

http://dx.doi.org/10.1038/s41598-017-04326-z]

[PMID: 28706256

[54] Rossich LE, Thomasz L, Nicola JP, et al. Effects of 2iodohexadecanal in the physiology of thyroid cells. Mol Cell Endocrinol 2016; 437: 292-301.

[http://dx.doi.org/10.1016/j.mce.2016.08.036] [PMID: 27568464]

[55] Ziros PG, Manolakou SD, Habeos IG, et al. Nrf2 is commonly activated in papillary thyroid carcinoma, and it controls antioxidant transcriptional responses and viability of cancer cells. J Clin Endocrinol Metab 2013; 98(8): E1422-7.

[http://dx.doi.org/10.1210/jc.2013-1510] [PMID: 23766517]

[56] Martinez VD, Vucic EA, Pikor LA, Thu KL, Hubaux R, Lam WL. Frequent concerted genetic mechanisms disrupt multiple components of the NRF2 inhibitor KEAP1/CUL3/RBX1 E3-ubiquitin ligase complex in thyroid cancer. Mol Cancer 2013; 12(1): 124. [http://dx.doi.org/10.1186/1476-4598-12-124] [PMID: 24138990]

[57] Crozier A, Clifford MN, Ashihara H. Plant Secondary Metabolites: Occurrence. Structure and Role in the Human Diet 2007.

[58] Gould KS. Nature's Swiss Army Knife: The Diverse Protective Roles of Anthocyanins in Leaves. J Biomed Biotechnol 2004; 2004(5): 314-20.

[http://dx.doi.org/10.1155/S1110724304406147] [PMID: 15577195]

[59] Dewick PM. Medicinal natural products: a biosynthetic approach. Medicinal natural products: a biosynthetic approach., 1997

[60] Croteau R. KTMLNG. Natural products (secondary metabolites) 2000

[61] Bravo L. Polyphenols: chemistry, dietary sources, metabolism, and nutritional significance. Nutr Rev 1998; 56(11): 317-33.

[http://dx.doi.org/10.1111/j.1753-4887.1998.tb01670.x] [PMID: 9838798]

[62] Han X, Shen T, Lou H, Han X, Shen T, Lou H. Dietary Polyphenols and Their Biological Significance. Int J Mol Sci 2007; 8: 95088 .

[http://dx.doi.org/10.3390/i8090950]

[63] Moudgal NR, Raghupathy E, Sarma PS. Studies on goitrogenic agents in food. III. Goitrogenic action of some glycosides isolated from edible nuts. J Nutr 1958; 66(2): 291-303. [http://dx.doi.org/10.1093/jn/66.2.291] [PMID: 13599069]

[64] Cai Y, Luo Q, Sun M, Corke H. Antioxidant activity and phenolic compounds of 112 traditional Chinese medicinal plants associated with anticancer. Life Sci 2004; 74(17): 2157-84. [http://dx.doi.org/10.1016/j.1fs.2003.09.047] [PMID: 14969719]

[65] Divi RL, Doerge DR. Inhibition of thyroid peroxidase by dietary flavonoids. Chem Res Toxicol 1996; 9(1): 16-23. [http://dx.doi.org/10.1021/tx950076m] [PMID: 8924586]

[66] Yin F, Giuliano AE, Van Herle AJ. Growth inhibitory effects of flavonoids in human thyroid cancer cell lines. Thyroid 1999; 9(4): 369-76.

[http://dx.doi.org/10.1089/thy.1999.9.369] [PMID: 10319943]

[67] Schröder-van der Elst JP, Smit JWA, Romijn HA, van der Heide D. Dietary flavonoids and iodine metabolism. Biofactors 2003; 19(34): 171-6.

[http://dx.doi.org/10.1002/biof.5520190310] [PMID: 14757968]
[68] Gaitan E, Lindsay RH, Reichert RD, et al. Antithyroid and goitrogenic effects of millet: role of C-glycosylflavones. J Clin Endocrinol Metab 1989; 68(4): 707-14.

[http://dx.doi.org/10.1210/jcem-68-4-707] [PMID: 2921306]

[69] Ferreira ACF, Lisboa PC, Oliveira KJ, Lima LP, Barros IA, Carvalho DP. Inhibition of thyroid type 1 deiodinase activity by flavonoids. Food Chem Toxicol 2002; 40(7): 913-7.

[http://dx.doi.org/10.1016/S0278-6915(02)00064-9]

[PMID: 12065212]

[70] Park CH, Han SE, Nam-goong IS, Kim YI, Kim ES. Combined Effects of Baicalein and Docetaxel on Apoptosis in 8505c Anaplas tic Thyroid Cancer Cells via Downregulation of the ERK and Akt / mTOR Pathways. 2018: 121-132

[71] Gaique TG, Lopes BP, Souza LL, Paula GSM, Pazos-Moura CC, Oliveira KJ. Cinnamon intake reduces serum T3 level and modulates tissue-specific expression of thyroid hormone receptor and target genes in rats. J Sci Food Agric 2016; 96(8): 2889-95. [http://dx.doi.org/10.1002/jsfa.7460] [PMID: 26374392]

[72] Nabavi SF, Moghaddam AH, Nabavi SM, Eslami S. Protective effect of curcumin and quercetin on thyroid function in sodium fluoride intoxicated rats. Fluoride 2011; 44: 147-52.

[73] Allegri L, Rosignolo F, Mio C, Filetti S, Baldan F, Damante G. Effects of nutraceuticals on anaplastic thyroid cancer cells. J Cancer Res Clin Oncol 2018; 144(2): 285-94.

[http://dx.doi.org/10.1007/s00432-017-2555-7] [PMID: 29197967]

[74] Sosić-Jurjević B, Filipović B, Ajdzanović V, et al. Suppressive effects of genistein and daidzein on pituitary-thyroid axis in orchidectomized middle-aged rats. Exp Biol Med (Maywood) 2010; 235(5): 590-8.

[http://dx.doi.org/10.1258/ebm.2009.009279] [PMID: 20463299]

[75] Dodurga Y, Eroğlu C, Seçme M, Elmas L, Avcı ÇB, ŞatıroğluTufan NL. Anti-proliferative and anti-invasive effects of ferulic acid in TT medullary thyroid cancer cells interacting with URG4/URGCP. Tumour Biol 2016; 37(2): 1933-40.

[http://dx.doi.org/10.1007/s13277-015-3984-z] [PMID: 26334619]

[76] Kang HJ, Youn YK, Hong MK, Kim LS. Antiproliferation and redifferentiation in thyroid cancer cell lines by polyphenol phytochemicals. J Korean Med Sci 2011; 26(7): 893-9.

[http://dx.doi.org/10.3346/jkms.2011.26.7.893] [PMID: 21738342]

[77] Divi RL, Chang HC, Doerge DR. Anti-thyroid isoflavones from soybean: isolation, characterization, and mechanisms of action. Biochem Pharmacol 1997; 54(10): 1087-96.

[http://dx.doi.org/10.1016/S0006-2952(97)00301-8]

[PMID: 9464451]

[78] Miler M, Jarić I, Živanović J, et al. Citrus flavanones mildly interfere with pituitary-thyroid axis in old-aged male rats. Acta Histochem 2017; 119(3): 292-301.

[http://dx.doi.org/10.1016/j.acthis.2017.02.005] [PMID: 28262328]

[79] Ferreira ACF, Neto JC, da Silva ACM, Kuster RM, Carvalho DP. Inhibition of thyroid peroxidase by Myrcia uniflora flavonoids. Chem Res Toxicol 2006; 19(3): 351-5.

[http://dx.doi.org/10.1021/tx0501684] [PMID: 16544938]

[80] Jo S, Ha TK, Han SH, et al. Myricetin Induces Apoptosis of Human Anaplastic Thyroid Cancer Cells via Mitochondria Dysfunction. Anticancer Res 2017; 37(4): 1705-10.

[http://dx.doi.org/10.21873/anticanres.11502] [PMID: 28373432]

[81] Gaitan E. Environmental Goitrogenesis. In: ed.^eds., 1989; pp. 52

[82] Chung HJ, Chung MJ, Houng SJ, et al. Toxicological evaluation of the isoflavone puerarin and its glycosides. Eur Food Res Technol 2009; 230: 145-53

[http://dx.doi.org/10.1007/s00217-009-1156-3]

[83] Giuliani C, Bucci I, Di Santo S, et al. The flavonoid quercetin inhibits thyroid-restricted genes expression and thyroid function. Food Chem Toxicol 2014; 66: 23-9.

[http://dx.doi.org/10.1016/j.fct.2014.01.016] [PMID: 24447974]

[84] Giuliani C, Noguchi Y, Harii N, et al. The flavonoid quercetin regulates growth and gene expression in rat FRTL-5 thyroid cells. Endocrinology 2008; 149(1): 84-92.

[http://dx.doi.org/10.1210/en.2007-0618] [PMID: 17962351]

[85] Sebai H, Hovsépian S, Ristorcelli E, Aouani E, Lombardo D, Fayet $\mathrm{G}$. Resveratrol increases iodide trapping in the rat thyroid cell line FRTL-5. Thyroid 2010; 20(2): 195-203.

[http://dx.doi.org/10.1089/thy.2009.0171] [PMID: 20151827]

[86] Shih A, Davis FB, Lin H-Y, Davis PJ. Resveratrol induces apoptosis in thyroid cancer cell lines via a MAPK- and p53-dependent mechanism. J Clin Endocrinol Metab 2002; 87(3): 1223-32. 
[http://dx.doi.org/10.1210/jcem.87.3.8345] [PMID: 11889192]

[87] Lin CJ, Lin CY, Chen Y, Huang SH, Wang SM. Rottlerin inhibits migration of follicular thyroid carcinoma cells by PKCdeltaindependent destabilization of the focal adhesion complex. J Cell Biochem 2010; 110(2): 428-37.

[PMID: 20225271]

[88] Jatwa R, Kar A, Pradesh M. Protective Effect of L-Ornithine-LAspartate and Silymarin on Chemically Induced Kidney Toxicity and. EXCLI J 2008; ••: 139-50.

[89] Radović B, Schmutzler C, Köhrle J. Xanthohumol stimulates iodide uptake in rat thyroid-derived FRTL-5 cells. Mol Nutr Food Res 2005; 49(9): 832-6.

[http://dx.doi.org/10.1002/mnfr.200500053] [PMID: 16092068]

[90] Renko K, Schäche S, Hoefig CS, et al. An Improved Nonradioactive Screening Method Identifies Genistein and Xanthohumol as Potent Inhibitors of Iodothyronine Deiodinases. Thyroid 2015; 25(8): 962-8.

[http://dx.doi.org/10.1089/thy.2015.0058] [PMID: 25962824]

[91] Leonard J, Koehrle J. Intracellular pathways of iodothyronine metabolism. In: Braverman L, Utiger R, ed.^eds.: Philadelphia, USA, 1996; pp. 136-173

[92] Huang WY, Cai YZ, Zhang Y. Natural phenolic compounds from medicinal herbs and dietary plants: potential use for cancer prevention. Nutr Cancer 2010; 62(1): 1-20.

[http://dx.doi.org/10.1080/01635580903191585]

[PMID: 20043255]

[93] Middleton E Jr, Kandaswami C, Theoharides TC, Kandaswami C, Theoharides TC, Theoharides TC. The effects of plant flavonoids on mammalian cells: implications for inflammation, heart disease, and cancer. Pharmacol Rev 2000; 52(4): 673-751. [PMID: 11121513]

[94] Izumi Y, Matsumura A, Wakita S, et al. Isolation, identification, and biological evaluation of Nrf2-ARE activator from the leaves of green perilla (Perilla frutescens var. crispa f. viridis). Free Radic Biol Med 2012; 53(4): 669-79.

[http://dx.doi.org/10.1016/j.freeradbiomed.2012.06.021] [PMID: 22749808]

[95] Lee D-S, Li B. Im N-K, Kim Y-C, Jeong G-S. 4,2',5'-Trihydroxy4'-methoxychalcone from Dalbergia odorifera exhibits antiinflammatory properties by inducing heme oxygenase-1 in murine macrophages. Int Immunopharmacol 2013; 16: 114-21.

[http://dx.doi.org/10.1016/j.intimp.2013.03.026]

[PMID: 23566812]

[96] Paredes-Gonzalez X, Fuentes F, Jeffery S, et al. Induction of NRF2-mediated gene expression by dietary phytochemical flavones apigenin and luteolin. Biopharm Drug Dispos 2015; 36(7): 440-51. [http://dx.doi.org/10.1002/bdd.1956] [PMID: 25904312]

[97] Huang CS, Lii CK, Lin AH, et al. Protection by chrysin, apigenin, and luteolin against oxidative stress is mediated by the Nrf2dependent up-regulation of heme oxygenase 1 and glutamate cysteine ligase in rat primary hepatocytes. Arch Toxicol 2013; 87(1): 167-78.

[http://dx.doi.org/10.1007/s00204-012-0913-4] [PMID: 22864849]

[98] Gao AM, Ke ZP, Wang JN, Yang JY, Chen SY, Chen H. Apigenin sensitizes doxorubicin-resistant hepatocellular carcinoma BEL7402/ADM cells to doxorubicin via inhibiting PI3K/Akt/Nrf2 pathway. Carcinogenesis 2013; 34(8): 1806-14.

[http://dx.doi.org/10.1093/carcin/bgt108] [PMID: 23563091]

[99] Lee C-Y, Chew E-H, Go M-L. Functionalized aurones as inducers of NAD(P)H:quinone oxidoreductase 1 that activate AhR/XRE and Nrf2/ARE signaling pathways: synthesis, evaluation and SAR. Eur J Med Chem 2010; 45(7): 2957-71.

[http://dx.doi.org/10.1016/j.ejmech.2010.03.023]

[PMID: 20392544]

[100] Zhang Z, Cui W, Li G, et al. Baicalein protects against 6-OHDAinduced neurotoxicity through activation of Keap1/Nrf2/HO-1 and involving PKC $\alpha$ and PI3K/AKT signaling pathways. J Agric Food Chem 2012; 60(33): 8171-82.

[http://dx.doi.org/10.1021/jf301511m] [PMID: 22838648]

[101] Liu X, Wang T, Liu X, et al. Biochanin A protects lipopolysaccharide/D-galactosamine-induced acute liver injury in mice by activating the Nrf2 pathway and inhibiting NLRP3 inflammasome activation. Int Immunopharmacol 2016; 38: 324-31.

[http://dx.doi.org/10.1016/j.intimp.2016.06.009] 27344638]

[PMID:
[102] Choi B-M, Kim B-R. Upregulation of heme oxygenase-1 by brazilin via the phosphatidylinositol 3-kinase/Akt and ERK pathways and its protective effect against oxidative injury. Eur J Pharmacol 2008; 580(1-2): 12-8.

[http://dx.doi.org/10.1016/j.ejphar.2007.10.044]

[PMID: $18021765]$

[103] Liang L, Luo M, Fu Y, et al. Cajaninstilbene acid (CSA) exerts cytoprotective effects against oxidative stress through the Nrf2dependent antioxidant pathway. Toxicol Lett 2013; 219(3): 254-61. [http://dx.doi.org/10.1016/j.toxlet.2013.03.008] [PMID: 23535287]

[104] Huang T-C, Chung Y-L, Wu M-L, Chuang S-M. Cinnamaldehyde enhances Nrf2 nuclear translocation to upregulate phase II detoxifying enzyme expression in HepG2 cells. J Agric Food Chem 2011; 59(9): 5164-71.

[http://dx.doi.org/10.1021/jf200579h] [PMID: 21469739]

[105] Kang ES, Woo IS, Kim HJ, et al. Up-regulation of aldose reductase expression mediated by phosphatidylinositol 3-kinase/Akt and Nrf2 is involved in the protective effect of curcumin against oxidative damage. Free Radic Biol Med 2007; 43(4): 535-45.

[http://dx.doi.org/10.1016/j.freeradbiomed.2007.05.006] [PMID 17640564]

[106] Shen G, Xu C, Hu R, et al. Modulation of nuclear factor E2-related factor 2-mediated gene expression in mice liver and small intestine by cancer chemopreventive agent curcumin. Mol Cancer Ther 2006; 5(1): 39-51.

[http://dx.doi.org/10.1158/1535-7163.MCT-05-0293] [PMID: 16432161]

[107] Balogun E, Hoque M, Gong P, et al. Curcumin activates the haem oxygenase-1 gene via regulation of Nrf2 and the antioxidantresponsive element. Biochem J 2003; 371(Pt 3): 887-95. [http://dx.doi.org/10.1042/bj20021619] [PMID: 12570874]

[108] Chapple SJ, Siow RCM, Mann GE. Crosstalk between Nrf2 and the proteasome: therapeutic potential of Nrf2 inducers in vascular disease and aging. Int J Biochem Cell Biol 2012; 44(8): 1315-20.

[http://dx.doi.org/10.1016/j.biocel.2012.04.021] [PMID: 22575091]

[109] Chong CM, Zhou ZY, Razmovski-Naumovski V, et al. Danshensu protects against 6-hydroxydopamine-induced damage of PC12 cells in vitro and dopaminergic neurons in zebrafish. Neurosci Lett 2013; 543: 121-5.

[http://dx.doi.org/10.1016/j.neulet.2013.02.069] [PMID: 23562886]

[110] Kim HJ, Lim SS, Park IS, Lim JS, Seo JY, Kim J-S. Neuroprotective effects of dehydroglyasperin $\mathrm{C}$ through activation of heme oxygenase-1 in mouse hippocampal cells. J Agric Food Chem 2012; 60(22): 5583-9.

[http://dx.doi.org/10.1021/jf300548b] [PMID: 22578244]

[111] Lee SE, Yang H, Son GW, et al. Eriodictyol protects endothelial cells against oxidative stress-induced cell death through modulating ERK/Nrf2/ARE-dependent heme oxygenase-1 expression. Int $\mathbf{J}$ Mol Sci 2015; 16(7): 14526-39.

[http://dx.doi.org/10.3390/ijms160714526] [PMID: 26132561]

[112] Lou H, Jing X, Ren D, Wei X, Zhang X. Eriodictyol protects against $\mathrm{H}(2) \mathrm{O}(2)$-induced neuron-like $\mathrm{PC} 12$ cell death through activation of Nrf2/ARE signaling pathway. Neurochem Int 2012; 61(2): 251-7.

[http://dx.doi.org/10.1016/j.neuint.2012.05.013]

[PMID: 22609376]

[113] Hu Q, Zhang DD, Wang L, Lou H, Ren D. Eriodictyol-7-Oglucoside, a novel Nrf2 activator, confers protection against cisplatin-induced toxicity. Food Chem Toxicol 2012; 50(6): 1927-32. [http://dx.doi.org/10.1016/j.fct.2012.03.059] [PMID: 22465804]

[114] Song HJ, Shin CY, Oh TY, Sohn UD. The protective effect of eupatilin on indomethacin-induced cell damage in cultured feline ileal smooth muscle cells: involvement of HO-1 and ERK. J Ethnopharmacol 2008; 118(1): 94-101.

[http://dx.doi.org/10.1016/j.jep.2008.03.010] [PMID: 18440740]

[115] Ma Z-C, Hong Q, Wang Y-G, et al. Ferulic acid protects human umbilical vein endothelial cells from radiation induced oxidative stress by phosphatidylinositol 3-kinase and extracellular signalregulated kinase pathways. Biol Pharm Bull 2010; 33(1): 29-34 [http://dx.doi.org/10.1248/bpb.33.29] [PMID: 20045931]

[116] Lee SE, Jeong SI, Yang H, Park C-S, Jin Y-H, Park YS. Fisetin induces Nrf2-mediated HO-1 expression through PKC- $\delta$ and p38 in human umbilical vein endothelial cells. J Cell Biochem 2011; 112(9): 2352-60.

[http://dx.doi.org/10.1002/jcb.23158] [PMID: 21520244] 
[117] Zhao X, Zou Y, Xu H, et al. Gastrodin protect primary cultured rat hippocampal neurons against amyloid-beta peptide-induced neurotoxicity via ERK1/2-Nrf2 pathway. Brain Res 2012; 1482: 13-21 [http://dx.doi.org/10.1016/j.brainres.2012.09.010] [PMID: 22982592]

[118] Ma W, Yuan L, Yu H, et al. Genistein as a neuroprotective antioxidant attenuates redox imbalance induced by $\beta$-amyloid peptides 25 35 in PC12 cells. Int J Dev Neurosci 2010; 28(4): 289-95. [http://dx.doi.org/10.1016/j.ijdevneu.2010.03.003]

[PMID: 20362658

[119] Wiegand $\mathrm{H}$, Wagner AE, Boesch-Saadatmandi C, Kruse H-P, Kulling S, Rimbach G. Effect of dietary genistein on Phase II and antioxidant enzymes in rat liver. Cancer Genomics Proteomics 2009; 6(2): 85-92.

[PMID: 19451092]

[120] Zhang $\mathrm{T}$, Wang $\mathrm{F}$, Xu H-X, et al. Activation of nuclear factor erythroid 2-related factor 2 and PPAR $\gamma$ plays a role in the genistein-mediated attenuation of oxidative stress-induced endothelial cell injury. Br J Nutr 2013; 109(2): 223-35.

[http://dx.doi.org/10.1017/S0007114512001110]

[PMID: 22716961

[121] Zhu C, Dong Y, Liu H, Ren H, Cui Z. Hesperetin protects against $\mathrm{H}_{2} \mathrm{O}_{2}$-triggered oxidative damage via upregulation of the Keap1Nrf2/HO-1 signal pathway in ARPE-19 cells. Biomed Pharmacother $2017 ; 88: 124-33$.

[http://dx.doi.org/10.1016/j.biopha.2016.11.089]

[PMID: 28103505]

[122] Elavarasan J, Velusamy P, Ganesan T, Ramakrishnan SK, Rajasekaran D, Periandavan K. Hesperidin-mediated expression of Nrf2 and upregulation of antioxidant status in senescent rat heart. J Pharm Pharmacol 2012; 64(10): 1472-82

[http://dx.doi.org/10.1111/j.2042-7158.2012.01512.x] [PMID: 22943178

[123] Gu J, Sun X, Wang G, Li M, Chi M. Icariside II enhances Nrf2 nuclear translocation to upregulate phase II detoxifying enzyme expression coupled with the ERK, Akt and JNK signaling pathways. Molecules 2011; 16(11): 9234-44.

[http://dx.doi.org/10.3390/molecules16119234] [PMID: 22051934]

[124] Lim JH, Park H-S, Choi J-K, Lee I-S, Choi HJ. Isoorientin induces Nrf2 pathway-driven antioxidant response through phosphatidylinositol 3-kinase signaling. Arch Pharm Res 2007; 30(12): 1590-8. [http://dx.doi.org/10.1007/BF02977329] [PMID: 18254247]

[125] Saw CLL, Guo Y, Yang AY, et al. The berry constituents quercetin, kaempferol, and pterostilbene synergistically attenuate reactive oxygen species: involvement of the Nrf2-ARE signaling pathway. Food Chem Toxicol 2014; 72: 303-11

[http://dx.doi.org/10.1016/j.fct.2014.07.038] [PMID: 25111660]

[126] Gao SS, Choi B-M, Chen XY, et al. Kaempferol suppresses cisplatin-induced apoptosis via inductions of heme oxygenase-1 and glutamate-cysteine ligase catalytic subunit in HEI-OC1 cell. Pharm Res $2010 ; 27(2): 235-45$.

[http://dx.doi.org/10.1007/s11095-009-0003-3] [PMID: 19937094]

[127] Hirose E, Matsushima M, Takagi K, et al. Involvement of heme oxygenase-1 in kaempferol-induced anti-allergic actions in RBL2H3 cells. Inflammation 2009; 32(2): 99-108.

[http://dx.doi.org/10.1007/s10753-009-9108-4] [PMID: 19214725]

[128] Lee BW, Chun SW, Kim SH, et al. Lithospermic acid B protects $\beta$ cells from cytokine-induced apoptosis by alleviating apoptotic pathways and activating anti-apoptotic pathways of Nrf2-HO-1 and Sirt1. Toxicol Appl Pharmacol 2011; 252(1): 47-54.

[http://dx.doi.org/10.1016/j.taap.2011.01.018] [PMID: 21295052]

[129] Chen W-C, Wang S-Y, Chiu C-C, et al. Lucidone suppresses hepatitis $\mathrm{C}$ virus replication by Nrf2-mediated heme oxygenase- 1 induction. Antimicrob Agents Chemother 2013; 57(3): 1180-91. [http://dx.doi.org/10.1128/AAC.02053-12] [PMID: 23254429]

[130] Kumar KJ, Yang HL, Tsai YC, et al. Lucidone protects human skin keratinocytes against free radical-induced oxidative damage and inflammation through the up-regulation of $\mathrm{HO}-1 / \mathrm{Nrf} 2$ antioxidant genes and down-regulation of $\mathrm{NF}-\kappa \mathrm{B}$ signaling pathway. Food Chem Toxicol 2013; 59: 55-66.

[http://dx.doi.org/10.1016/j.fct.2013.04.055] [PMID: 23712098]

[131] Tang X, Wang H, Fan L, et al. Luteolin inhibits Nrf2 leading to negative regulation of the Nrf2/ARE pathway and sensitization of human lung carcinoma A549 cells to therapeutic drugs. Free Radic Biol Med 2011; 50(11): 1599-609. [http://dx.doi.org/10.1016/j.freeradbiomed.2011.03.008] [PMID: 21402146]

[132] Chian S, Thapa R, Chi Z, Wang XJ, Tang X. Luteolin inhibits the Nrf2 signaling pathway and tumor growth in vivo. Biochem Biophys Res Commun 2014; 447(4): 602-8.

[http://dx.doi.org/10.1016/j.bbrc.2014.04.039] [PMID: 24747074]

[133] Lee MH, Han MH, Lee DS, et al. Morin exerts cytoprotective effects against oxidative stress in $\mathrm{C} 2 \mathrm{C} 12$ myoblasts via the upregulation of Nrf2-dependent HO-1 expression and the activation of the ERK pathway. Int J Mol Med 2017; 39(2): 399-406 [http://dx.doi.org/10.3892/ijmm.2016.2837] [PMID: 28035409]

[134] Cho BO, Yin HH, Park SH, Byun EB, Ha HY, Jang SI. Antiinflammatory activity of myricetin from Diospyros lotus through suppression of NF- $\kappa \mathrm{B}$ and STAT1 activation and Nrf2-mediated HO-1 induction in lipopolysaccharide-stimulated RAW264.7 macrophages. Biosci Biotechnol Biochem 2016; 80(8): 1520-30.

[http://dx.doi.org/10.1080/09168451.2016.1171697]

[PMID: 27068250]

[135] Zhang B, Chen Y, Shen Q, et al. Myricitrin attenuates high glucose-induced apoptosis through activating Akt-Nrf2 signaling in H9c2 cardiomyocytes. Molecules 2016; 21(7): 1-13.

[http://dx.doi.org/10.3390/molecules2 1070880] [PMID: 27399653]

[136] Ramprasath T, Senthamizharasi M, Vasudevan V, Sasikumar S Yuvaraj S, Selvam GS. Naringenin confers protection against oxidative stress through upregulation of Nrf2 target genes in cardiomyoblast cells. J Physiol Biochem 2014; 70(2): 407-15. [http://dx.doi.org/10.1007/s13105-014-0318-3] [PMID: 24526395]

[137] Lou H, Jing X, Wei X, Shi H, Ren D, Zhang X. Naringenin protects against 6-OHDA-induced neurotoxicity via activation of the Nrf2/ARE signaling pathway. Neuropharmacology 2014; 79: 3808 . [http://dx.doi.org/10.1016/j.neuropharm.2013.11.026]

[PMID: 24333330

[138] Esmaeili MA, Alilou M. Naringenin attenuates CCl4 -induced hepatic inflammation by the activation of an Nrf2-mediated pathway in rats. Clin Exp Pharmacol Physiol 2014; 41(6): 416-22.

[http://dx.doi.org/10.1111/1440-1681.12230] [PMID: 24684352]

[139] Kil J-S, Son Y, Cheong Y-K, et al. Okanin, a chalcone found in the genus Bidens, and 3-penten-2-one inhibit inducible nitric oxide synthase expression via heme oxygenase-1 induction in RAW264.7 macrophages activated with lipopolysaccharide. J Clin Biochem Nutr 2012; 50(1): 53-8.

[http://dx.doi.org/10.3164/jcbn.11-30] [PMID: 22247601]

[140] Yeh CT, Ching LC, Yen GC. Inducing gene expression of cardiac antioxidant enzymes by dietary phenolic acids in rats. J Nutr Biochem $2009 ; 20(3): 163-71$.

[http://dx.doi.org/10.1016/j.jnutbio.2008.01.005] 18547798]

[141] Yang Y-C, Lii C-K, Lin A-H, et al. Induction of glutathione synthesis and heme oxygenase 1 by the flavonoids butein and phloretin is mediated through the ERK/Nrf2 pathway and protects against oxidative stress. Free Radic Biol Med 2011; 51(11): 2073-81.

[http://dx.doi.org/10.1016/j.freeradbiomed.2011.09.007] [PMID: 21964506]

[142] Ryu J, Zhang R, Hong BH, et al. Phloroglucinol attenuates motor functional deficits in an animal model of Parkinson's disease by enhancing Nrf2 activity. PLoS One 2013; 8(8)e71178 [http://dx.doi.org/10.1371/journal.pone.0071178] 23976995]

[143] Lee HH, Park SA, Almazari I, Kim EH, Na HK, Surh YJ. Piceatannol induces heme oxygenase-1 expression in human mammary epithelial cells through activation of ARE-driven Nrf2 signaling. Arch Biochem Biophys 2010; 501(1): 142-50. [http://dx.doi.org/10.1016/j.abb.2010.06.011] [PMID: 20558128]

[144] Son Y, Byun SJ, Pae HO. Involvement of heme oxygenase-1 expression in neuroprotection by piceatannol, a natural analog and a metabolite of resveratrol, against glutamate-mediated oxidative injury in HT22 neuronal cells. Amino Acids 2013; 45(2): 393-401. [http://dx.doi.org/10.1007/s00726-013-1518-9] [PMID: 23712764]

[145] Varì R, D’Archivio M, Filesi C, et al. Protocatechuic acid induces antioxidant/detoxifying enzyme expression through JNK-mediated Nrf2 activation in murine macrophages. J Nutr Biochem 2011; 22(5): 409-17.

[http://dx.doi.org/10.1016/j.jnutbio.2010.03.008] 20621462]
[PMID: 
[146] Hwang YP, Jeong HG. Mechanism of phytoestrogen puerarinmediated cytoprotection following oxidative injury: estrogen receptor-dependent up-regulation of PI3K/Akt and HO-1. Toxicol Appl Pharmacol 2008; 233(3): 371-81.

[http://dx.doi.org/10.1016/j.taap.2008.09.006] [PMID: 18845176]

[147] Tanigawa S, Fujii M, Hou DX. Action of Nrf2 and Keap1 in AREmediated NQO1 expression by quercetin. Free Radic Biol Med 2007; 42(11): 1690-703.

[http://dx.doi.org/10.1016/j.freeradbiomed.2007.02.017] [PMID: 17462537]

[148] Palsamy P, Subramanian S. Resveratrol protects diabetic kidney by attenuating hyperglycemia-mediated oxidative stress and renal inflammatory cytokines via Nrf2-Keap1 signaling. Biochim Biophys Acta 2011; 1812(7): 719-31.

[http://dx.doi.org/10.1016/j.bbadis.2011.03.008] [PMID: 21439372]

[149] Park EJ, Lim JH, Nam SI, Park JW, Kwon TK. Rottlerin induces heme oxygenase-1 (HO-1) up-regulation through reactive oxygen species (ROS) dependent and PKC $\delta$-independent pathway in human colon cancer HT29 cells. Biochimie 2010; 92(1): 110-5.

[http://dx.doi.org/10.1016/j.biochi.2009.10.001] [PMID: 19833168]

[150] Tian R, Yang W, Xue Q, et al. Rutin ameliorates diabetic neuropathy by lowering plasma glucose and decreasing oxidative stress via Nrf2 signaling pathway in rats. Eur J Pharmacol 2016; 771: 84-92.

[http://dx.doi.org/10.1016/j.ejphar.2015.12.021]

[PMID: 26688570]

[151] Jeong G-S, Lee D-S, Li B, Lee H-J, Kim E-C, Kim Y-C. Effects of sappanchalcone on the cytoprotection and anti-inflammation via heme oxygenase-1 in human pulp and periodontal ligament cells. Eur J Pharmacol 2010; 644(1-3): 230-7.

[http://dx.doi.org/10.1016/j.ejphar.2010.06.059]

[PMID: 20621084]

[152] Zhao F, Shi D, Li T, Li L, Zhao M. Silymarin attenuates paraquatinduced lung injury via Nrf2-mediated pathway in vivo and in vitro. Clin Exp Pharmacol Physiol 2015; 42(9): 988-98.

[http://dx.doi.org/10.1111/1440-1681.12448] [PMID: 26173462]

[153] Manigandan K, Manimaran D, Jayaraj RL, Elangovan N, Dhivya $\mathrm{V}$, Kaphle A. Taxifolin curbs NF-кB-mediated Wnt/ $\beta$-catenin signaling via up-regulating Nrf2 pathway in experimental colon carcinogenesis. Biochimie 2015; 119: 103-12.

[http://dx.doi.org/10.1016/j.biochi.2015.10.014]

[PMID: 26482805]

[154] Malar DS, Suryanarayanan V, Prasanth MI, Singh SK, Balamurugan $K$, Devi KP. Vitexin inhibits $A \beta_{25-35}$ induced toxicity in Neuro2 a cells by augmenting Nrf-2/HO-1 dependent antioxidant pathway and regulating lipid homeostasis by the activation of LXR- $\alpha$. Toxicol In Vitro 2018; 50: 160-71.

[http://dx.doi.org/10.1016/j.tiv.2018.03.003] [PMID: 29545167]

[155] Yao J, Zhang B, Ge C, Peng S, Fang J. Xanthohumol, a polyphenol chalcone present in hops, activating Nrf2 enzymes to confer protection against oxidative damage in PC12 cells. J Agric Food Chem 2015; 63(5): 1521-31.

[http://dx.doi.org/10.1021/jf505075n] [PMID: 25587858]

[156] Lv H, Liu Q, Wen Z, Feng H, Deng X, Ci X. Xanthohumol ameliorates lipopolysaccharide (LPS)-induced acute lung injury via induction of AMPK/GSK3 $\beta$-Nrf2 signal axis. Redox Biol 2017; 12: 311 24.

[http://dx.doi.org/10.1016/j.redox.2017.03.001] [PMID: 28285192]

[157] Krajka-Kuźniak V, Paluszczak J, Baer-Dubowska W. Xanthohumol induces phase II enzymes via Nrf2 in human hepatocytes in vitro. Toxicol In Vitro 2013; 27(1): 149-56.

[http://dx.doi.org/10.1016/j.tiv.2012.10.008] [PMID: 23085367]

[158] Lee IS, Lim J, Gal J, et al. Anti-inflammatory activity of xanthohumol involves heme oxygenase-1 induction via NRF2-ARE signaling in microglial BV2 cells. Neurochem Int 2011; 58(2): 15360.

[http://dx.doi.org/10.1016/j.neuint.2010.11.008]

[PMID: 21093515]

[159] Tan AC, Konczak I, Sze DMY, Ramzan I. Molecular pathways for cancer chemoprevention by dietary phytochemicals. Nutr Cancer 2011; 63(4): 495-505.

[http://dx.doi.org/10.1080/01635581.2011.538953] [PMID: 21500099]
[160] Jomova K, Vondrakova D, Lawson M, Valko M. Metals, oxidative stress and neurodegenerative disorders. Mol Cell Biochem 2010; 345(1-2): 91-104.

[http://dx.doi.org/10.1007/s11010-010-0563-x] [PMID: 20730621]

[161] Shu L, Khor TO, Lee J-H, et al. Epigenetic CpG demethylation of the promoter and reactivation of the expression of Neurog 1 by curcumin in prostate LNCaP cells. AAPS J 2011; 13(4): 606-14.

[http://dx.doi.org/10.1208/s12248-011-9300-y] [PMID: 21938566]

[162] Sithisarn P, Michaelis M, Schubert-Zsilavecz M, Cinatl J Jr. Differential antiviral and anti-inflammatory mechanisms of the flavonoids biochanin A and baicalein in H5N1 influenza A virusinfected cells. Antiviral Res 2013; 97(1): 41-8.

[http://dx.doi.org/10.1016/j.antiviral.2012.10.004]

[PMID: 23098745]

[163] Gao A-M, Ke Z-P, Wang J-N, Yang J-Y, Chen S-Y, Chen H. Apigenin sensitizes doxorubicin-resistant hepatocellular carcinoma BEL-7402/ADM cells to doxorubicin via inhibiting PI3K/Akt/Nrf2 pathway. Carcinogenesis 2013; 34(8): 1806-14.

[http://dx.doi.org/10.1093/carcin/bgt108] [PMID: 23563091]

[164] Cheung KL, Kong A-N. Molecular targets of dietary phenethyl isothiocyanate and sulforaphane for cancer chemoprevention. AAPS J 2010; 12(1): 87-97.

[http://dx.doi.org/10.1208/s12248-009-9162-8] [PMID: 20013083]

[165] Shapiro TA, Fahey JW, Wade KL, Stephenson KK, Talalay P. Human metabolism and excretion of cancer chemoprotective glucosinolates and isothiocyanates of cruciferous vegetables. Cancer Epidemiol Biomarkers Prev 1998; 7(12): 1091-100.

[PMID: 9865427]

[166] Fahey JW, Wehage SL, Holtzclaw WD, et al. Protection of humans by plant glucosinolates: efficiency of conversion of glucosinolates to isothiocyanates by the gastrointestinal microflora. Cancer Prev Res (Phila) 2012; 5(4): 603-11.

[http://dx.doi.org/10.1158/1940-6207.CAPR-11-0538] [PMID: 22318753 ]

[167] Dinkova-Kostova AT, Wang XJ. Induction of the Keap1/Nrf2/ARE pathway by oxidizable diphenols. Chem Biol Interact 2011; 192(12): 101-6.

[http://dx.doi.org/10.1016/j.cbi.2010.09.010] [PMID: 20846517]

[168] Jeong W-S, Keum Y-S, Chen C, et al. Differential expression and stability of endogenous nuclear factor E2-related factor 2 (Nrf2) by natural chemopreventive compounds in HepG2 human hepatoma cells. J Biochem Mol Biol 2005; 38(2): 167-76. [PMID: 15826493]

[169] Keum YS, Owuor ED, Kim BR, Hu R, Kong ANT. Involvement of Nrf2 and JNK1 in the activation of antioxidant responsive element (ARE) by chemopreventive agent phenethyl isothiocyanate (PEITC). Pharm Res 2003; 20(9): 1351-6.

[http://dx.doi.org/10.1023/A:1025737622815] [PMID: 14567627]

[170] Korenori Y, Tanigawa S, Kumamoto T, et al. Modulation of Nrf2/Keap1 system by Wasabi 6-methylthiohexyl isothiocyanate in ARE-mediated NQO1 expression. Mol Nutr Food Res 2013; 57(5): 854-64.

[http://dx.doi.org/10.1002/mnfr.201200689] [PMID: 23390006]

[171] Langer P, Greer MA. Antithyroid activity of some naturally occurring isothiocyanates in vitro. Metabolism 1968; 17(7): 596-605. [http://dx.doi.org/10.1016/0026-0495(68)90018-8] [PMID 5656976]

[172] Okulicz M, Hertig I. Benzyl isothiocyanate disturbs lipid metabolism in rats in a way independent of its thyroid impact following in vivo long-term treatment and in vitro adipocytes studies. J Physiol Biochem 2013; 69(1): 75-84.

[http://dx.doi.org/10.1007/s13105-012-0189-4] [PMID: 22798227]

[173] Chen C, Pung D, Leong V, et al. Induction of detoxifying enzymes by garlic organosulfur compounds through transcription factor Nrf2: effect of chemical structure and stress signals. Free Radic Biol Med 2004; 37(10): 1578-90.

[http://dx.doi.org/10.1016/j.freeradbiomed.2004.07.021] [PMID: 15477009]

[174] Gong P, Hu B, Cederbaum AI. Diallyl sulfide induces heme oxygenase-1 through MAPK pathway. Arch Biochem Biophys 2004; 432(2): 252-60.

[http://dx.doi.org/10.1016/j.abb.2004.09.024] [PMID: 15542064]

[175] Shin HA, Cha YY, Park MS, Kim JM, Lim YC. Diallyl sulfide induces growth inhibition and apoptosis of anaplastic thyroid cancer cells by mitochondrial signaling pathway. Oral Oncol 2010; 46(4): e15-8. 
[http://dx.doi.org/10.1016/j.oraloncology.2009.10.012] [PMID: 20219414]

[176] Kalayarasan S, Sriram N, Sureshkumar A, Sudhandiran G. Chromium (VI)-induced oxidative stress and apoptosis is reduced by garlic and its derivative S-allylcysteine through the activation of Nrf2 in the hepatocytes of Wistar rats. J Appl Toxicol 2008; 28(7): 908-19.

[http://dx.doi.org/10.1002/jat.1355] [PMID: 18548744]

[177] Saravanan G, Ponmurugan P. Antidiabetic effect of S-allylcysteine: effect on thyroid hormone and circulatory antioxidant system in experimental diabetic rats. J Diabetes Complications 2012; 26(4): 280-5.

[http://dx.doi.org/10.1016/j.jdiacomp.2012.03.024]

[PMID: 22541895]

[178] Ping Z, Liu W, Kang Z, et al. Sulforaphane protects brains against hypoxic-ischemic injury through induction of $\mathrm{Nrf2}$-dependent phase 2 enzyme. Brain Res 2010; 1343: 178-85.

[http://dx.doi.org/10.1016/j.brainres.2010.04.036]

[PMID: 20417626]

[179] Lin W, Wu RT, Wu T, Khor T-O, Wang H, Kong A-N. Sulforaphane suppressed LPS-induced inflammation in mouse peritoneal macrophages through Nrf2 dependent pathway. Biochem Pharmacol 2008; 76(8): 967-73.

[http://dx.doi.org/10.1016/j.bcp.2008.07.036] [PMID: 18755157]

[180] Bai Y, Cui W, Xin Y, et al. Prevention by sulforaphane of diabetic cardiomyopathy is associated with up-regulation of Nrf2 expression and transcription activation. J Mol Cell Cardiol 2013; 57: 8295.

[http://dx.doi.org/10.1016/j.yjmcc.2013.01.008] [PMID: 23353773]

[181] Yoon H-Y, Kang N-I, Lee H-K, Jang KY, Park J-W, Park B-H. Sulforaphane protects kidneys against ischemia-reperfusion injury through induction of the Nrf2-dependent phase 2 enzyme. Biochem Pharmacol 2008; 75(11): 2214-23.

[http://dx.doi.org/10.1016/j.bcp.2008.02.029] [PMID: 18407246]

[182] Wang L, Tian Z, Yang Q, et al. Sulforaphane inhibits thyroid cancer cell growth and invasiveness through the reactive oxygen species-dependent pathway. Oncotarget 2015; 6(28): 25917-31.

[http://dx.doi.org/10.18632/oncotarget.4542] [PMID: 26312762]

[183] Singh SV, Pan SS, Srivastava SK, et al. Differential induction of $\mathrm{NAD}(\mathrm{P}) \mathrm{H}$ :quinone oxidoreductase by anti-carcinogenic organosulfides from garlic. Biochem Biophys Res Commun 1998; 244(3): 917-20.

[http://dx.doi.org/10.1006/bbrc.1998.8352] [PMID: 9535768]

[184] Thomas M, Zhang P, Noordine M-L, Vaugelade P, Chaumontet C, Duée P-H. Diallyl disulfide increases rat $\mathrm{h}$-ferritin, L-ferritin and transferrin receptor genes in vitro in hepatic cells and in vivo in liver. J Nutr 2002; 132(12): 3638-41.

[http://dx.doi.org/10.1093/jn/132.12.3638] [PMID: 12468600]

[185] Wu CC, Sheen LY, Chen HW, Tsai SJ, Lii CK. Effects of organosulfur compounds from garlic oil on the antioxidation system in rat liver and red blood cells. Food Chem Toxicol 2001; 39(6): 563-9. [http://dx.doi.org/10.1016/S0278-6915(00)00171-X] [PMID: 11346486]

[186] Langer P. Antithyroid action in rats of small doses of some naturally occurring compounds. Endocrinology 1966; 79(6): 1117-22. [http://dx.doi.org/10.1210/endo-79-6-1117] [PMID: 4162816]

[187] Chartoumpekis DV, Ziros PG, Chen JG, Groopman JD, Kensler TW, Sykiotis GP. Broccoli sprout beverage is safe for thyroid hormonal and autoimmune status: Results of a 12-week randomized trial. Food Chem Toxicol 2019; 126: 1-6. [http://dx.doi.org/10.1016/j.fct.2019.02.004] [PMID: 30735751]

[188] Cao X, Xiao H, Zhang Y, Zou L, Chu Y, Chu X. 1, 5Dicaffeoylquinic acid-mediated glutathione synthesis through activation of Nrf2 protects against OGD/reperfusion-induced oxidative stress in astrocytes. Brain Res 2010; 1347: 142-8.

[http://dx.doi.org/10.1016/j.brainres.2010.05.072] [PMID: 20513363]

[189] Kapeta S, Chondrogianni N, Gonos ES. Nuclear erythroid factor 2mediated proteasome activation delays senescence in human fibroblasts. J Biol Chem 2010; 285(11): 8171-84.

[http://dx.doi.org/10.1074/jbc.M109.031575] [PMID: 20068043]

[190] Papaevgeniou N, Sakellari M, Jha S, et al. 18a-Glycyrrhetinic Acid Proteasome Activator Decelerates Aging and Alzheimer's Disease Progression in Caenorhabditis elegans and Neuronal Cultures. Antioxid Redox Signal 2016; 25(16): 855-69.

[http://dx.doi.org/10.1089/ars.2015.6494] [PMID: 26886723]
[191] Hwang YP, Yun HJ, Chun HK, et al. Protective mechanisms of 3caffeoyl, 4-dihydrocaffeoyl quinic acid from Salicornia herbacea against tert-butyl hydroperoxide-induced oxidative damage. Chem Biol Interact 2009; 181(3): 366-76.

[http://dx.doi.org/10.1016/j.cbi.2009.07.017] [PMID: 19647727]

[192] González-Burgos E, Carretero ME, Gómez-Serranillos MP. Nrf2dependent neuroprotective activity of diterpenoids isolated from Sideritis spp. J Ethnopharmacol 2013; 147(3): 645-52. [http://dx.doi.org/10.1016/j.jep.2013.03.062] [PMID: 23548583]

[193] Yang SM, Ka SM, Hua KF, et al. Antroquinonol mitigates an accelerated and progressive IgA nephropathy model in mice by activating the Nrf2 pathway and inhibiting T cells and NLRP3 inflammasome. Free Radic Biol Med 2013; 61: 285-97.

[http://dx.doi.org/10.1016/j.freeradbiomed.2013.03.024] [PMID: 23567192]

[194] Satoh T, Kosaka K, Itoh K, et al. Carnosic acid, a catechol-type electrophilic compound, protects neurons both in vitro and in vivo through activation of the Keap1/Nrf2 pathway via S-alkylation of targeted cysteines on Keap1. J Neurochem 2008; 104(4): 1116-31. [http://dx.doi.org/10.1111/j.1471-4159.2007.05039.x] [PMID: 17995931]

[195] Martin D, Rojo AI, Salinas M, et al. Regulation of heme oxygenase-1 expression through the phosphatidylinositol 3-kinase/Akt pathway and the Nrf2 transcription factor in response to the antioxidant phytochemical carnosol. J Biol Chem 2004; 279(10): 891929.

[http://dx.doi.org/10.1074/jbc.M309660200] [PMID: 14688281]

[196] Seo WY, Goh AR, Ju SM, et al. Celastrol induces expression of heme oxygenase-1 through ROS/Nrf2/ARE signaling in the HaCaT cells. Biochem Biophys Res Commun 2011; 407(3): 535-40. [http://dx.doi.org/10.1016/j.bbrc.2011.03.053] [PMID: 21414301]

[197] Kim SH, Kang JG, Kim CS, et al. Cytotoxic effect of celastrol alone or in combination with paclitaxel on anaplastic thyroid carcinoma cells. Tumour Biol 2017; 39(5)1010428317698369

[http://dx.doi.org/10.1177/1010428317698369] [PMID: 28459364]

[198] Park SY, Jin ML, Ko MJ, Park G, Choi YW. Antineuroinflammatory Effect of Emodin in LPS-Stimulated Microglia: Involvement of AMPK/Nrf2 Activation. Neurochem Res 2016; 41(11): 2981-92.

[http://dx.doi.org/10.1007/s11064-016-2018-6] [PMID: 27538959]

[199] Jing N, Jing Z, ZhanSheng Z, Hui G, Qing W. Pro-apoptic effect of Aloe emodin on human thyroid cancer cell K1. Xiandai Shengwu Yixue Jinzhan 2010; 10: 3225-7.

[200] Lyu JH, Lee GS, Kim KH, et al. ent-kaur-16-en-19-oic Acid, isolated from the roots of Aralia continentalis, induces activation of Nrf2. J Ethnopharmacol 2011; 137(3): 1442-9.

[http://dx.doi.org/10.1016/j.jep.2011.08.024] [PMID: 21884778]

[201] González-Burgos E, Carretero ME, Gómez-Serranillos MP. Kaurane diterpenes from Sideritis spp. exert a cytoprotective effect against oxidative injury that is associated with modulation of the Nrf2 system. Phytochemistry 2013; 93: 116-23.

[http://dx.doi.org/10.1016/j.phytochem.2013.03.017] [PMID: 23642391]

[202] Yap WH, Khoo KS, Ho ASH, Lim YM. Maslinic acid induces HO1 and NOQ1 expression via activation of Nrf2 transcription factor. Biomedicine \& Preventive Nutrition 2012; 2: 51-8.

[http://dx.doi.org/10.1016/j.bionut.2011.12.005]

[203] Lee Y-M, Auh QS, Lee D-W, et al. Involvement of Nrf2-mediated upregulation of heme oxygenase-1 in mollugin-induced growth inhibition and apoptosis in human oral cancer cells. BioMed Res Int 2013; 2013210604

[http://dx.doi.org/10.1155/2013/210604] [PMID: 23738323]

[204] Du Y, Villeneuve NF, Wang XJ, et al. Oridonin confers protection against arsenic-induced toxicity through activation of the Nrf2mediated defensive response. Environ Health Perspect 2008; 116(9): 1154-61.

[http://dx.doi.org/10.1289/ehp.11464] [PMID: 18795156]

[205] Son TG, Camandola S, Arumugam TV, et al. Plumbagin, a novel Nrf2/ARE activator, protects against cerebral ischemia. J Neurochem 2010; 112(5): 1316-26.

[http://dx.doi.org/10.1111/j.1471-4159.2009.06552.x] [PMID: 20028456]

[206] Yu J, Ren P, Zhong T, et al. Pseudolaric acid B inhibits proliferation in SW579 human thyroid squamous cell carcinoma. Mol Med Rep 2015; 12(5): 7195-202.

[http://dx.doi.org/10.3892/mmr.2015.4418] [PMID: 26460192] 
[207] Lee D-S, Choi H-G, Wan Woo K, et al. Pulchellamin G, an amino acid-sesquiterpene lactone, from Saussurea pulchella suppresses lipopolysaccharide-induced inflammatory responses via heme oxygenase-1 expression in murine peritoneal macrophages. Eur $\mathbf{J}$ Pharmacol 2013; 715(1-3): 123-32.

[http://dx.doi.org/10.1016/j.ejphar.2013.05.033]

[PMID: 23742862]

[208] Tao S, Zheng Y, Lau A, et al. Tanshinone I activates the Nrf2dependent antioxidant response and protects against As(III)induced lung inflammation in vitro and in vivo. Antioxid Redox Signal 2013; 19(14): 1647-61.

[http://dx.doi.org/10.1089/ars.2012.5117] [PMID: 23394605]

[209] Zhang H-S, Wang S-Q. Nrf2 is involved in the effect of tanshinone IIA on intracellular redox status in human aortic smooth muscle cells. Biochem Pharmacol 2007; 73(9): 1358-66.

[http://dx.doi.org/10.1016/j.bcp.2007.01.004] [PMID: 17303087]

[210] Chen F, Liu Y, Wang S, et al. Triptolide, a Chinese herbal extract, enhances drug sensitivity of resistant myeloid leukemia cell lines through downregulation of HIF-1 $\alpha$ and Nrf2. Pharmacogenomics 2013; 14(11): 1305-17.

[http://dx.doi.org/10.2217/pgs.13.122] [PMID: 23930677]

[211] Yu H, Shi L, Zhao S, et al. Triptolide Attenuates Myocardial Ischemia/Reperfusion Injuries in Rats by Inducing the Activation of Nrf2/HO-1 Defense Pathway. Cardiovasc Toxicol 2016; 16(4): 325-35.

[http://dx.doi.org/10.1007/s12012-015-9342-y] [PMID: 26391895]

[212] Zhu W, Hu H, Qiu P, Yan G. Triptolide induces apoptosis in human anaplastic thyroid carcinoma cells by a p53-independent but NF-kappaB-related mechanism. Oncol Rep 2009; 22(6): 1397-401. [PMID: 19885592]

[213] Nakamura Y, Yoshida C, Murakami A, Ohigashi H, Osawa T, Uchida K. Zerumbone, a tropical ginger sesquiterpene, activates phase II drug metabolizing enzymes. FEBS Lett 2004; 572(1-3): 245-50.

[http://dx.doi.org/10.1016/j.febslet.2004.07.042]

[PMID: 15304356]

[214] Park SY, Park DJ, Kim YH, Kim Y, Choi Y-W, Lee S-J. Schisandra chinensis $\alpha$-iso-cubebenol induces heme oxygenase-1 expression through PI3K/Akt and Nrf2 signaling and has antiinflammatory activity in Porphyromonas gingivalis lipopolysaccharide-stimulated macrophages. Int Immunopharmacol 2011; 11(11): 1907-15.

[http://dx.doi.org/10.1016/j.intimp.2011.07.023]

[PMID: 21840424]

[215] Palliyaguru DL, Chartoumpekis DV, Wakabayashi $\mathrm{N}$, et al. Withaferin A induces Nrf2-dependent protection against liver injury: Role of Keap1-independent mechanisms. Free Radic Biol Med 2016; 101: 116-28.

[http://dx.doi.org/10.1016/j.freeradbiomed.2016.10.003] [PMID: 27717869]

[216] Yarnell E, Abascal K. Botanical Medicine for Thyroid Regulation. Altern Complement Ther 2006; 12: 107-12.

[http://dx.doi.org/10.1089/act.2006.12.107]

[217] Chandra AK, Mukhopadhyay S, Lahari D, Tripathy S. Goitrogenic content of Indian cyanogenic plant foods \& their in vitro antithyroidal activity. Indian J Med Res 2004; 119(5): 180-5. [PMID: 15218979]

[218] Ferreira ACF, Rosenthal D, Carvalho DP. Thyroid peroxidase inhibition by Kalanchoe brasiliensis aqueous extract. Food Chem Toxicol 2000; 38(5): 417-21.

[http://dx.doi.org/10.1016/S0278-6915(00)00017-X] [PMID: 10762727]

[219] Kar A, Panda S, Bharti S. Relative efficacy of three medicinal plant extracts in the alteration of thyroid hormone concentrations in male mice. J Ethnopharmacol 2002; 81(2): 281-5.

[http://dx.doi.org/10.1016/S0378-8741(02)00048-X] [PMID: 12065164]

[220] Chandra AK, De N. Goitrogenic/antithyroidal potential of green tea extract in relation to catechin in rats. Food Chem Toxicol 2010; 48(8-9): 2304-11.

[http://dx.doi.org/10.1016/j.fct.2010.05.064] [PMID: 20561943]

[221] Rinner B, Siegl V, Pürstner P, et al. Activity of novel plant extracts against medullary thyroid carcinoma cells. Anticancer Res 2004; 24(2A): 495-500.
[PMID: 15152949]

[222] Gerhäuser C, Klimo K, Hümmer W, et al. Identification of 3hydroxy- $\beta$-damascone and related carotenoid-derived aroma compounds as novel potent inducers of Nrf2-mediated phase 2 response with concomitant anti-inflammatory activity. Mol Nutr Food Res 2009; 53(10): 1237-44.

[http://dx.doi.org/10.1002/mnfr.200800492] [PMID: 19753606]

[223] Chen H-H, Chen Y-T, Huang Y-W, Tsai H-J, Kuo C-C. 4Ketopinoresinol, a novel naturally occurring ARE activator, induces the Nrf2/HO-1 axis and protects against oxidative stressinduced cell injury via activation of PI3K/AKT signaling. Free Radic Biol Med 2012; 52(6): 1054-66.

[http://dx.doi.org/10.1016/j.freeradbiomed.2011.12.012] [PMID: 22245092]

[224] Lee B-H, Hsu W-H, Chang Y-Y, Kuo H-F, Hsu Y-W, Pan T-M. Ankaflavin: a natural novel PPAR $\gamma$ agonist upregulates Nrf2 to attenuate methylglyoxal-induced diabetes in vivo. Free Radic Biol Med 2012; 53(11): 2008-16.

[http://dx.doi.org/10.1016/j.freeradbiomed.2012.09.025] [PMID: 23022408]

[225] Kim KC, Kang KA, Zhang R, et al. Up-regulation of Nrf2mediated heme oxygenase- 1 expression by eckol, a phlorotannin compound, through activation of Erk and PI3K/Akt. Int J Biochem Cell Biol 2010; 42(2): 297-305.

[http://dx.doi.org/10.1016/j.biocel.2009.11.009] [PMID: 19931411]

[226] Ohnuma T, Komatsu T, Nakayama S, Nishiyama T, Ogura K, Hiratsuka A. Induction of antioxidant and phase 2 drugmetabolizing enzymes by falcarindiol isolated from Notopterygium incisum extract, which activates the Nrf2/ARE pathway, leads to cytoprotection against oxidative and electrophilic stress. Arch Biochem Biophys 2009; 488(1): 34-41.

[http://dx.doi.org/10.1016/j.abb.2009.06.006] [PMID: 19527678]

[227] Wang Y, Zhao H, Lin C, Ren J, Zhang S, Forsythiaside A. Forsythiaside A Exhibits Anti-inflammatory Effects in LPS-Stimulated BV2 Microglia Cells Through Activation of Nrf2/HO-1 Signaling Pathway. Neurochem Res 2016; 41(4): 659-65.

[http://dx.doi.org/10.1007/s11064-015-1731-x] [PMID: 26498935]

[228] Liu C-L, Chiu Y-T, Hu M-L. Fucoxanthin enhances HO-1 and NQO1 expression in murine hepatic BNL CL.2 cells through activation of the Nrf2/ARE system partially by its pro-oxidant activity. J Agric Food Chem 2011; 59(20): 11344-51.

[http://dx.doi.org/10.1021/jf2029785] [PMID: 21919437]

[229] Lee K-M, Kang K, Lee SB, Nho CW. Nuclear factor-E2 (Nrf2) is regulated through the differential activation of ERK1/2 and PKC $\alpha / \beta I I$ by Gymnasterkoreayne B. Cancer Lett 2013; 330(2): 225-32. [http://dx.doi.org/10.1016/j.canlet.2012.11.053] [PMID: 23219897]

[230] Boesch-Saadatmandi C, Wagner AE, Graeser AC, Hundhausen C, Wolffram S, Rimbach G. Ochratoxin A impairs Nrf2-dependent gene expression in porcine kidney tubulus cells. J Anim Physiol Anim Nutr (Berl) 2009; 93(5): 547-54.

[http://dx.doi.org/10.1111/j.1439-0396.2008.00838.x] [PMID: 18547363 ]

[231] Kay HY, Kim YW, Ryu DH, Sung SH, Hwang SJ, Kim SG. Nrf2mediated liver protection by sauchinone, an antioxidant lignan, from acetaminophen toxicity through the PKC $\delta$-GSK $3 \beta$ pathway. Br J Pharmacol 2011; 163(8): 1653-65.

[http://dx.doi.org/10.1111/j.1476-5381.2010.01095.x] [PMID: 21039417]

[232] Chiu PY, Chen N, Leong PK, Leung HY, Ko KM. Schisandrin B elicits a glutathione antioxidant response and protects against apoptosis via the redox-sensitive ERK/Nrf2 pathway in H9c2 cells. Mol Cell Biochem 2011; 350(1-2): 237-50.

[http://dx.doi.org/10.1007/s11010-010-0703-3] [PMID: 21193948]

[233] Kang KA, Lee KH, Park JW, et al. Triphlorethol-A induces heme oxygenase-1 via activation of ERK and NF-E2 related factor 2 transcription factor. FEBS Lett 2007; 581(10): 2000-8.

[http://dx.doi.org/10.1016/j.febslet.2007.04.022] 17467702]

[234] Egner PA, Chen JG, Zarth AT, et al. Rapid and sustainable detoxication of airborne pollutants by broccoli sprout beverage: results of a randomized clinical trial in China. Cancer Prev Res (Phila) 2014; 7(8): 813-23.

[http://dx.doi.org/10.1158/1940-6207.CAPR-14-0103] [PMID: 24913818] 